ASD TR 61-446

\title{
DEVELOPMENT OF A Ti-Al-Cb ALLOY FOR USE AT $1200^{\circ}-1800^{\circ} \mathrm{F}$
}

TECHNICAL DOCUMENTARY REPORT No. ASD TR 61-446

MARCH 1962

\author{
DIRECTORATE OF MATERIALS AND PROCESSES \\ AERONAUTICAL SYSTEMS DIVISION \\ AIR FORCE SYSTEMS COMMAND \\ WRIGHT-PATTERSON AIR FORCE BASE, OHIO
}

PROJECT No. 7351, TASK No. 735105

(Prepared under Contract No. AF 33(616)-7262 by the Armour Research Foundation, Chicago, Ill.;

Joseph B. McAndrew and Charles R. Simcoe, authors) 


\section{DISCLAIMER}

This report was prepared as an account of work sponsored by an agency of the United States Government. Neither the United States Government nor any agency Thereof, nor any of their employees, makes any warranty, express or implied, or assumes any legal liability or responsibility for the accuracy, completeness, or usefulness of any information, apparatus, product, or process disclosed, or represents that its use would not infringe privately owned rights. Reference herein to any specific commercial product, process, or service by trade name, trademark, manufacturer, or otherwise does not necessarily constitute or imply its endorsement, recommendation, or favoring by the United States Government or any agency thereof. The views and opinions of authors expressed herein do not necessarily state or reflect those of the United States Government or any agency thereof. 


\section{DISCLAIMER}

Portions of this document may be illegible in electronic image products. Images are produced from the best available original document. 


\section{NOTICES}

When Government drawings, specifications, or other data are used for any purpose other than in connection with a definitely related Government procurement operation, the United States Government thereby incurs no responsibility nor any obligation whatsoever; and the fact that the Government may have formulated, furnished, or in any way supplied the said drawings, specifications, or other data, is not to be regarded by implication or otherwise as in any manner licensing the holder or any other person or corporation, or conveying any rights or permission to manufacture, use, or sell any patented invention that may in any way be related thereto.

Qualified requesters may obtain copies of this report from the Armed Services Technical Information Agency, (ASTIA), Arlington Hall Station, Arlington 12, Virginia.

This report has been released to the Office of Technical Services, U. S. Department of Commerce, Washington 25, D. C., for sale to the general public.

Copies of ASD Technical Reports and Technical Notes should not be returned to the Aeronautical Systems Division unless return is required by security considerations, contractual obligations, or notice on a specific document. 
This report was prepared by Armour Research Foundation under USAF Contract No. AF 33(616)-7262, which was initiated under Project No. 7351, "Metallic Materials," Task No. 73519, "Titanium Metal and Alloys." It was administered under the direction of Directorate of Materials and Processes, Deputy for Technology, Aeronautical Systems Division, with Mr. Paul Hendricks acting as Project Engineer.

This report covers the period from I May 1960 to 31 July 1961. Earlier work on the same program has been reported in WADD TR 60-99 (April, 1960).

Personnel of Armour Research Foundation who made major contributions to this program were: C. R. Simcoe, supervisor; J. B. McAndrew, project engineer; and J. E. Anderson, technician. The data reported are recorded in ARF Logbook No. C-1196. This report is identified as ARF Report 2201-15. 
Titanium-base alloys contalning major amounts of columbium and aluminum are being studied with the object of developing new high-temperature alloys of low density. This report presents the findings of the second year of this program, derived from the preparation and examination of (1) thirty-five quaternary alloys containing small additions of tin, hafnium, or zirconium, (2) four high-purity ternary alloys, and (3) ten-pound melts of $\mathrm{T1}-15 \mathrm{Cb}-10 \mathrm{Al}$ and Ti-17.5Cb-15Al.

In a number of alloys, improved tensile properties and oxidation resistance resulted from the addition of tin, hafnium, or zirconium, and in some instances very high strength-denslity rallus wele maintained up to $180 n^{\circ} \mathrm{F}$. The properties of high-purity alloys were similar to those of alloys prepared with sponge titanium. It is recommended that further effort should be directed toward the more highly alloyed compositions, including those containing hafnium and zicronium. In addition, six alloys previously prepared have been selected for continued study.

This report has been reviewed and is approved.

FOR THE COMMANDER:

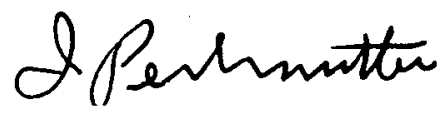

I. PERLMUTTER

Chief, Physical Metallurgy Branch Metals and Ceramics Laboratory Directorate of Materials and Processes 


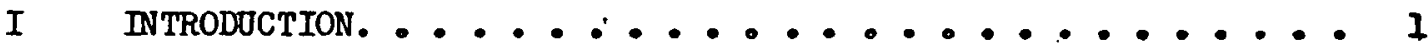

II EXPERTMENTAL PROCEDURES .................. I

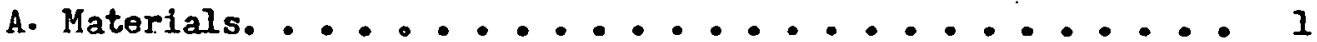

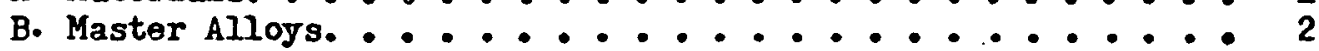

c. Melting. ................... 2

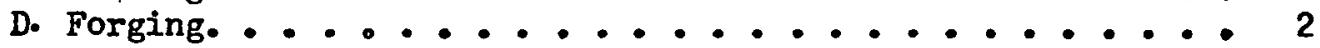

E. Rolling. ...................... 2

F. Heat Treating. .................... 3

G. Oxidation. .................... 3

H. Density....................... 3

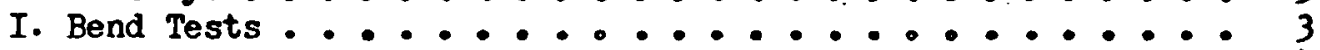

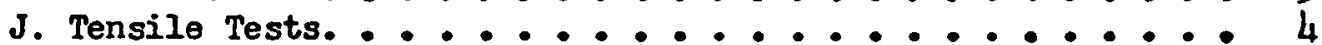

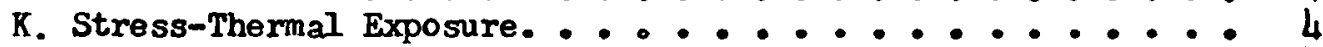

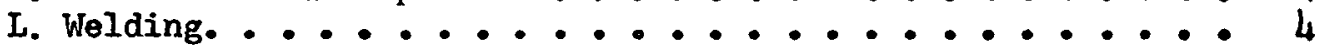

III EXPERTMENTAI RESULTS. .................... 4

A. Button Melts .................... 4

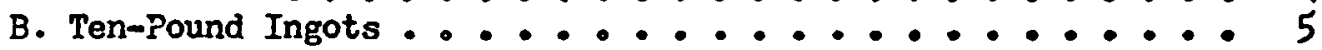

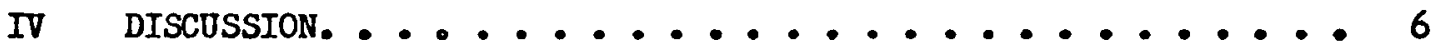

V RECOMMENDATIONS ..................... II

vI SJMMARI ....................... Il 


\section{LIST OF ILLUSTRATIONS}

\section{Figure}

Paire

I Hounsfieid Tensile Specimen. . . . . . . . . . 32

2 Specifications for 1-Inch Gage Length Sheet Tensile Specimen • 33

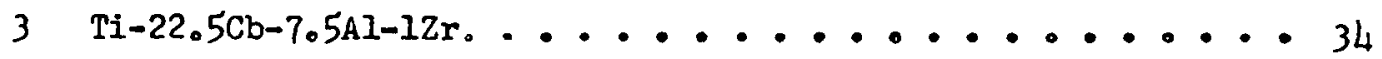

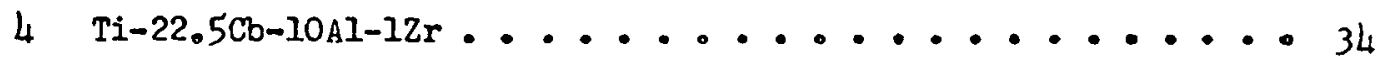

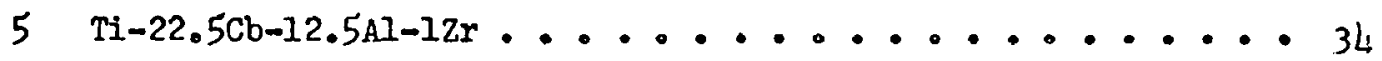

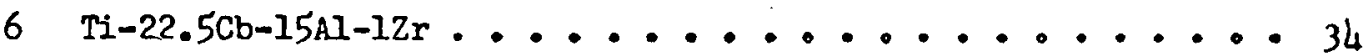

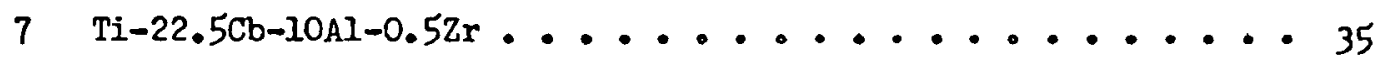

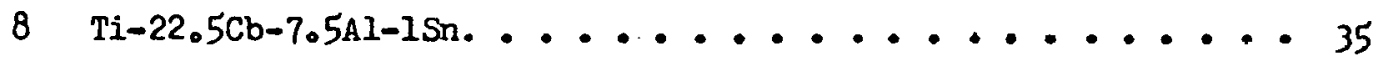

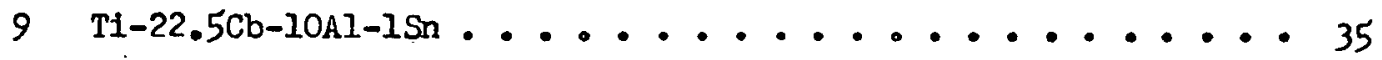

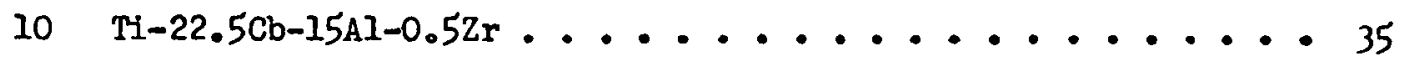

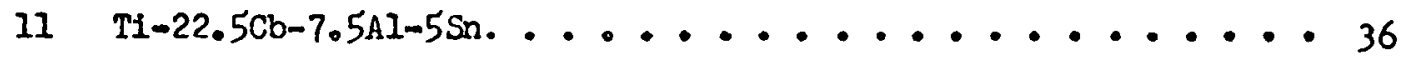

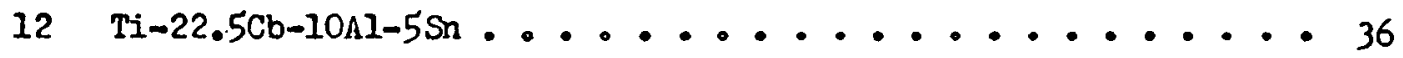

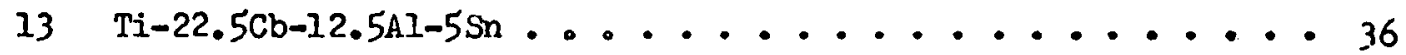

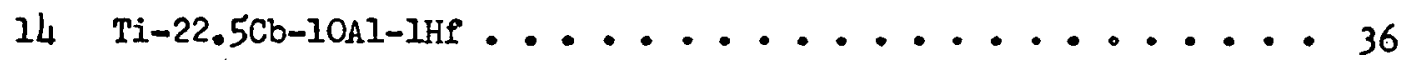

$15 \mathrm{Ti}-22.5 \mathrm{Cb}-12.5 \mathrm{Al}-\mathrm{IHf}$. . . . . . . . . . 37

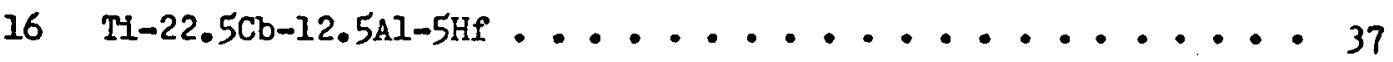


T'able

Page

I Analyses of Columbium Ingots. ............. 13

II Forglng Tenperatures. . . . . . . . . . . . I4

III Densities of Forged Alloys. . . . . . . . . 16

IV Oxidation of Ti.tanium Alloys Exposed to Still Air at $1830^{\circ} \mathrm{F}$

$\left(1000^{\circ} \mathrm{C}\right.$ ) for 84 Hours ...................... 13

$\checkmark$ Oxidation of Titanium Alloys Exposed to Still Air at $1630^{\circ} \mathrm{F}$

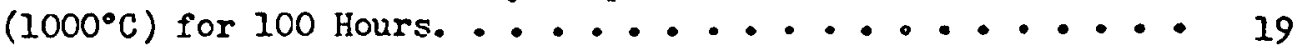

VI Short-Time Tensile Data for Titanium Alloys . . . . . . 20

VII Guided Bend Test Data for Titanium Alloy Sheet Approximately 1/16-Inch Thickness ................ 27

VIII Room-Temperature Tensile Results for Sheet Ti-15Cb-10Al with Several Heat Treatments and Stress-Thermal Exposures. . . 28

IX Room-Temperature Tensile Results for Sheet Ti-17.5Cb-15Al with Several Heat Treatments and Stress-Thermal Exposures - 29

X Tensile Properties of Ti-22.5Cb-10Al and Two Modifications. - 30

XI Tensile Properties of Ti-22.5Cb-12.5AI and Two Modifications. 31 


\section{INTROLUCTION}

Previous work has shown that the addition of substantial amounts of both aluminum and columbium to titanium produces alloys which are forgeable, light, oxidation resistant, and strong in short-time tests at elevated temperatures. This desirable combination of properties is sufficiently attractive to call for a complete investigation of the potential of the Ti-kl-Cb syster, and the data reported here should help to provide a basis for comprehensive evaluation of this type of alloy. It has been our intention to proceed with a methodical experimental study as long as such an approach might be fruitful, leaving until a later time the fitting together of observed facts into a theoretical structure which might then suggest means for further improvement in properties.

The information reported here falls into three categories: (1) the effect of purity on several ternary alloys; (2) the effect of small additions of zirconium, hafnium, or tin on alloys containing $22.5 \%$ columbium at several levels of aluminum content; and (3) the preparation and evaluation of sheet from ten-pound ingots of $\mathrm{Ti}-17.5 \mathrm{Cb}-15 \mathrm{Al}$ and $\mathrm{Ti}-15 \mathrm{Cb}-1 \mathrm{CAl}$.

\section{FYYPERIMENTAL PROCEDURES}

\section{A. Materials}

Except for the high-purity alloys, all melts were prepared with a single lot of magnesium-reduced sponge titanium containing $0.03 \% \mathrm{Fe}$ and having a hardness of $96 \mathrm{BHN}$, according to the supplier. For the high-purity alloys, the titanium was E.P. ("electropotential") crystals of special purity。

Two lots of electron-beam-melted columbium were purchased. The supplier' analyses and hardness determinations for the ingots from which the lots were processed are shown in Table I. The material was received as $1 / 2$ in. by $1 / 8$ in. strip, which was then cold rolled to 0.030 in., sheared into small pieces suitable for melting, cleaned with $\mathrm{CCl}_{4}$, and etched for two minutes in a solution containing 1 part $\mathrm{HF}, 5$ parts $\mathrm{HNO}_{3}$, 14 parts $\mathrm{H}_{2} \mathrm{O}_{0}$

The aluminum was of $99.99 \%$ minimum purity, with the reported impurities being $0.002 \% \mathrm{Cu}, 0.003 \% \mathrm{Fe}, 0.001 \% \mathrm{St}$, and $0.001 \% \mathrm{Mg}$.

Mamuscript released by the authors August 1961 for publication as a WADD Technical Report. 


\section{B. Master Allojs}

For the ten-found ingot of $\mathrm{T} i-15 \mathrm{Cb}-20 \mathrm{Al}$, a master alloy with the composition $\mathrm{Cb}-4 \mathrm{OAI}$ was melted as a series of $175-\mathrm{g}$ buttons, which were crushed and blended. For the ten-pound ingot of $\mathrm{Ti}-17.5 \mathrm{Cb}-15 \mathrm{Al}$, a master alloy, $\mathrm{Cb}-46.15 \mathrm{Al}$, was similarly prepared.

All of the quaternary and high-purity ternary alloys were made with the master alloy $\mathrm{Ti}-30 \mathrm{Cb}$, which was melted as 100-g buttons, cold rolled to sheet, cut into small pieces, washed in $\mathrm{CCl}_{4}$, and etched for two minutes in $\mathrm{H}_{2} \mathrm{O}-\mathrm{HNO}_{3}-\mathrm{HF}$ solution.

C. Melting

The quaternary and high-purity temary alloys were melted as 150- 6 pancake ingots by the nonconsumable-electrode arc melting process, each ingot being inverted and remelted four times to insure homogeneity. Each ingot was weighed after melting as a check against contamination, tungsten pickup, or loss of material.

The larger ingots of $\mathrm{Ti}-15 \mathrm{Cb}-10 \mathrm{AI}$ and $\mathrm{Ti}-17.5 \mathrm{Cb}-15 \mathrm{Al}$ were first melted in a nonconsumable-electrode, hopper-fed arc furnace. The resulting ingots were quartered longitudinally, and the four sections of each ingot were welded end to end to form a consumable electrode, which was remelted in a helium atmosphere. The final ingots were 4 in. in diameter and weighed $13 \mathrm{lb}$ and $10 \mathrm{lb}$ respectively.

\section{Forging}

Initial forging was done with a forge hammer, on flat-face dies. Forging of as-cast pancake ingots to rod by this method constitutes a severe test of forgeability. The rods were subsequently finished from approximately $1 / 2$ in. diameter to $3 / 8$ in. in swage blocks, also with the hamer. The 10-1b ingots were forged to $1.75-$ in. slab and conditioned for rolling by milling to $1.5-$ in. plate.

\section{E. Rolling}

The Ti-15Cb-10AI plate was cut into three pieces. The first of these was rolled from $1.5 \mathrm{in}$. to 0.078 in, at $1700^{\circ} \mathrm{F}$, with reheating before each pass. The other two pieces were rolled to $0.150 \mathrm{in}$. at $1700^{\circ} \mathrm{F}$; then one was finished to 0.082 in. at $1650^{\circ} \mathrm{F}$, and the other was rolled to 0.076 in. at $1600^{\circ} \mathrm{F}$.

An attempt was made to roll the Ti-17.5Cb-15Al plate at $1800^{\circ} \mathrm{F}$. This temperature was too low, and the plate "alligatored" before appreciable reduction was obtained. The plate was salvaged by cutting into three smaller pieces and milling off the fractured surfaces. One piece was further sectioned and used to find the lowest feasible rolling terperatures, which were $2050^{\circ} \mathrm{F}$ for the initial rolling ard $190^{\circ} \mathrm{F}$ for finishing. The two remaining sections were then rolled to 0.075 in. at these temperatures. 
All sheets were sandblasted before the final three passes to ensure good surface finish, although this did not seem to be really necessary, since the oxide was fairly thin and smooth. The finished sheets were again sandblasted and then pickled in $\mathrm{H}_{2} \mathrm{O}-\mathrm{HNO}_{3}-\mathrm{HF}$ solution.

Rolling was done on a two-high mill, and the final sheet thickness was: limited by the roll pressure obtainable.

\section{F. Heat Treating}

Heat treatment of sheet material (bend and tensile specimens) was carried out in air, and surface oxide was then removed on a belt sander.

Hounsfield Tensometer specimens were heat treated in sealed Vycor bulbs containing a partial pressure of argon. They were etched lightly before testing, as were similar specimens which had not been heat treated.

\section{G. Oxdiation}

Oxidation exposures were made by placing the specimens in open porcelain crucibles in a muffle furnace at $1830^{\circ} \mathrm{F}\left(1000^{\circ} \mathrm{C}\right)$ for $100 \mathrm{hr}$. Upon removal from the furnace, the crucibles were covered so that any scale which spalled during cooling would be retained with the specimen. After the woight gains were determined, the depth of oxidation was measured by removing the oxide with abrasive until clean metal was reached, and remeasuring a selected dimension with micrometer calipers.

One set of 21 specimens was exposed in glazed porcelain crucibles. Although similar crucibles had been used successfully before, this exposure caused unusually severe attack, and the results were discarded. It is thought that the glaze contained sufficient chloride ion to cause accelerated attack. Eight of the same alloys were run again in unglazed crucibles, and the results were then consistent with previous data. (A control specimen of Ti-22.5Cb-12.5Al gave a direct correlation with previous oxddation runs.) Another set of 22 alloys was then mu in unglazed crucibles, and, in this case also, the results appeared reasonable.

\section{H. Density}

Densities were determined, by measuring, with an analytical balance, the loss of weight in water at room temperature. Some of the determinations were made on the ends of tensile specimens; in other cases, oxidation specimens were used prior to the oxidation exposure. The lattor were cylinders 0.375 in. in diameter by $0.50 \mathrm{in.}$ long, weighing a little more than 4 grams.

I. Bend. Tests

Bend tests were performed in a Di-Acro guided bend fixture, the specimens being about $1 / 2$ in. wide and 4 to 6 in. long. A specimen vas considered to have passed the test if it did not exhibit cracks visible at 10X magnification after being bent to $180^{\circ}$ before springback. The severity of bend is expressed as $R_{t}$, the ratio of mandrel radius to sheet thickness. 


\section{J. Tensile Tests}

All tensile tests of the quaternary and high-purity ternary alloys were performed with the specimen shown in Fig. 1, using a Hounsfield Tensometer equipped with a Wild-barfield furnace and an electronic temperature controller. in auxiliary thermocouple and potentiometer provided a check of the temperature at the midpoint of the specimen, and the ccntroller was adjusted to give the required potentiometer reading. The subzero tests were performed with the specimen immersed in a bath of dry ice and acetone, the temperature of which was measured with a thermometer.

The Tensometer was operated at a crosshead speed of $1 / 8 \mathrm{in} / \mathrm{min}$, with a strain magnification of 8 to 1 . This magnification is rather low, and the yield strength values are therefore designated as approximations.

Tensile specimens of $\mathrm{T} i-15 \mathrm{Cb}-10 \mathrm{Al}$ and $\mathrm{T} i-17.5 \mathrm{Cb}-15 \mathrm{Al}$ from the large ingots were as shown in Fig. 2. This design was not found to be very satisfactory for these alloys. Many specimens broke through the pin hole, and this occurred even when the thickness at the pin hole was left much greater than in the gage length. These sheet specimens were tested at room temperature on a 60,000-1b Baldwin-Southwark machine equipped with an autographic recorder and extensometer of the microformer type. The loading rate was from 200 to $400 \mathrm{lb} / \mathrm{min}$.

\section{K. Stress-Thermal Exposure}

Stress-thermal exposure of sheet tensile specimens was carried out in air on conventional creep-rupture machines with 20 to 1 lever arms. Temperatures were controlled to $-3^{\circ} \mathrm{F}$ along the gage length of the specimen.

\section{Welding}

Welds were made with the TIG process, and were of the bead-cn-plate type, but with $100 \%$ penetration of the sheet.

\section{EXPERTMENTAL RESJLTS}

\section{A. Button Melts \\ 1. Forging}

The forging temperatures for various alloys are shown in Table II. With the exception of two buttons, all alloys were forged without difficulty at. the temperatures shown. One button of Ti-22.5Cb-15Al-5Hf cracked at $2300^{\circ} \mathrm{F}$ and continued breaking up at $2350^{\circ} \mathrm{F}$. A duplicate forged well at $2300^{\circ} \mathrm{F}$. The reason for this is not known. Ti-22.5Cb-15Al-5Sn did not forge at $2250^{\circ}$ or $2300^{\circ} \mathrm{F}$, but did forge well at $2460^{\circ}{ }^{\circ}$. 
It was judged that most of the alloys could have been forged at temperatures at least $100^{\circ}$ or $200^{\circ} \mathrm{F}$ lower than those employed.

\section{Density}

Densities of the forged alloys are shown in Table III. They show no anomalies, and require no special comments.

\section{Oxidation}

The results of two oxidation runs are shown in Tables IV and $V$. The first was made with the ends from broken tensile specimens, and included one ternary alloy; the second was made with cylindrical specinens and Included four ternary. alloys for comparison.

\section{Tensile Properties}

Table VI shows short-time tensile properties of the button-melt alloys. Except as noted, all specimens were in the as-forged, air-cooled condition.

\section{Metallography}

Some photomicrographs of typical forged structures of the quaternary alloys are shown in Figures 3 to 16. It may be seen that the microstructures are rather complex, and a definitive interpretation of them should not be attempted at this time. It is evident that these are transformation structures, formed as a consequence of the high forging temperatures. Some interesting observations may be made even though information is lacking concerning phase relationships and transformation kinetics. Three alloys which had very good properties were those in which $1 \mathrm{Zr}$, 1Hf, or $5 \mathrm{Hf}$ were added to Ti-22.5Cb-12.5Al (Figs. 5, 6, 7). These have similar structures in which a fine-grained transformation product is seen, with the prior large-grained $\beta$ structure still visible. Ti-22.5Cb-12.5Al-1Hf and Ti-22.5Cb-12.5Al-5Hf appear remarkably similar in view of the difference in properties. Structures such as those of Ti-22Cb-10Al-12r (Fig. 4) and $\mathrm{TH}-22.5 \mathrm{Cb}-7.5 \mathrm{Al}-1 \mathrm{Sn}$ (Fig. 8) are representative of many of the alloys not shown. Aluminum content appeared to be a stronger determinant of as-forged structure than did the quaternary additions, although this may be due, in part, to differences in forging temperatures.

\section{B. Ten-Pound Ingots}

\section{Bend Tests}

Nelther Ti-25Cb-20Al nor Ti-17.5Cb-15Al showed much bend ductility in the as-rolled condition. Several simple heat treatments were applied to both alloys with the object of improving ductility and learning more about the heat-treatment response of the two alloys. The results of these tests are shown in Table VII. 
Tables VIII and IX show the tensile properties of Ti-15Cb-10AI and Ti-17.5Cb-15Al sheet in the as-forged, heat-treated, and stress-thermally exposed conditions. The heat treatments were necessarily chosen on the basis of very limited information, and are not likely to be optimum.

3. Welds

Weld beads in the center of Ti-17.5Cb-15Al sheet caused transverse cracks to form at each end because of thermal stresses. The cracks extended into the base metal for $1 / 2$ to $11 / 2$ in. on each side of the weld. The sheet on which this was observed had been heat treated $1 \mathrm{I} / 2 \mathrm{hr}$ at $1600^{\circ} \mathrm{F}$, and was expected to have better ductility than the as-rolled sheet. Bend tests of the base metal showed that this was not the case.

Ti-15Cb-10Al welds did not show such cracks after welding. However, the welds in both alloys were brittle in bend tests. Fractures occurred in the heat-affected zone immediately adjacent to the weld in Ti-15Cb-10Al, and in both heat-affected zone and weld metal in Ti-17.5Cb-15Al.

\section{DISCUSSION}

From this investigation, a number of facts have been learned that indicate clearly in which directions further progress may be expected and what difficulties require primary attention. Certainly a great deal remains to be done, yet the summation of available data is quite encouraging. The more important findings will be enumerated and discussed individually。

1. Tensile properties of the high-purity alloys in the as-forged condition did not deviate in a consistent fashion from the properties of corresponding sponge-base alloys. The differences observed were such as might be accounted for by random variations in structure established during the forging operation. The very high strength of the Ti-20Cb-17.5Al specimen tested at $1200^{\circ} \mathrm{F}$ is noteworthy (UTS 185,000 psi, YS 164,000 psi, elongation $2.5 \%$, RA 3.5\%). This specimen had a yield-strength-to-density ratio of about 1,000,000. It remains to be seen whether such strength can be obtained consistently and in combination with other necessary properties; but, if such an achievement could be realized, it would represent a considerable advancement in the technology of high-temperature alloys.

2. Zirconium additions up to $2 \%$, and tin or hafnium up to $5 \%$ were beneficial rather than harmful with respect to oxidation resistance. Weight gains as low as $4.4 \mathrm{mg} / \mathrm{cm}^{2}$ were measured after a $1830^{\circ} \mathrm{F}\left(1000^{\circ} \mathrm{C}\right.$ ) exposure for $100 \mathrm{hr}$, and in most cases the loss of metal through oxidation amounted to less than 
0.001 in. This is sufficient oxidation resistance to suggest testing at higher temperatures, and also to encourage experimenting with alloys with columbium contents other than $22.5 \%$.

3. Improved high-temperature strength and greater ductility were obtained by the addition of hafnium or zirconium, and a few alloys containing tin were also better than the corresponding termary alloys.

Table X compares the tensile properties of Ti-22.5Cb-10Al with those of the same alloy containing $0.5 \mathrm{Zr}$ or $1 \mathrm{Hf}$. It may be seen that, whereas the ternary alloy was brittle at room temperature, the alloy with $0.52 \mathrm{r}$ had $3 \%$ elongation and $5 \%$ reduction in area, and the one with $2 H f$ had $9 \%$ elongation and $8 \%$ reduction in area. The room-temperature strengths of the quaternary alloys were lower, but this is of lesser importance in alloys intended for high-temperature use. At $1200^{\circ} \mathrm{F}$, the alloys with hafnium and zirconium were lower in strength, but at $1400^{\circ} \mathrm{F}$ the alloy with $0.5 \mathrm{Zr}$ had $73 \%$ higher yield strength and that with IHf had $76 \%$ higher yield strength than the ternary. At $1600^{\circ} \mathrm{F}$ the yield strengths of the quaternary alloys were about double that of the ternary. These are certainly remarkable effects for such small additions.

Table XI shows a similar comparison for $\mathrm{Ti}-22.5 \mathrm{Cb}-12.5 \mathrm{Al}$ and the same alloy containing $1 \mathrm{Hf}$ or $1 \mathrm{Zr}$. Again, the ternary alloy was brittle at room temperature, and the alloy with 1 Hf had $6 \%$ elongation and $7 \%$ reduction in area, while that with $12 r$ had $7 \%$ elongation and $13 \%$ reduction in area. The strengths of the quaternaries were lower at $1200^{\circ} \mathrm{F}$; at $1400^{\circ} \mathrm{F}$ the yield strengths of the three were approximately the same, with the quaternaries having higher ultimate strengths and ductilities. At $1600^{\circ} \mathrm{F}$ the yield strength of the alloy with Iff was $17 \%$ higher, and that of the alloy with $1 \mathrm{Zr}$ was $10 \%$ higher than the ternary, with the quaternaries again having higher ductility.

Ti-22.5Cb-12.5Al-5Hf had the same room-temperature ductility as the alloy with $1 \mathrm{Hf}$, but the high-iemperature strength was further improved. The yield strength at $1600^{\circ} \mathrm{F}$ was $40 \%$ higher than that of the ternary alloy. At $1800^{\circ} \mathrm{F}$, the yield strength of $\mathrm{Ti}-22.5 \mathrm{Cb}-12.5 \mathrm{Al}-5 \mathrm{Hf}$ was slightly higher than that of $\mathrm{Ti}-22.5 \mathrm{Cb}-12.5 \mathrm{Al}$ at $1600^{\circ} \mathrm{F}$, and it was about $20 \%$ higher than that of $\mathrm{Ti}-22.5 \mathrm{Cb}-$ 12.5Al-1Hf at $1800^{\circ} \mathrm{s}$.

The alloy $\mathrm{Ti}-22.5 \mathrm{Cb}-15 \mathrm{Al}-0.5 \mathrm{Zr}$ was brittle in the as-forged condition at room temperature, but at $1600^{\circ} \mathrm{F}$ it had $29 \%$ higher yield strength than the same alloy without zirconium. The quaternary alloy (Ti-22.5Cb-15A.1-0.5Zr) had, at $1800^{\circ} \mathrm{F}$, an ultimate strength of $88,900 \mathrm{psi}$ and a yield strength of approximately 79,000 psi. The ultimate-strength-to-density ratio is therefore 522,000 and the yield-strength-to-density ratio, 460,000. These are extremely high values for this temperature.

Ti-22. $5 \mathrm{Cb}-15 \mathrm{Al}-5 \mathrm{Sn}$ was strong at $1600^{\circ} \mathrm{F}$, having an ultimate strength of 109,300 psi and a yield of 96,000 psi. However, it was relatively weak at $1800^{\circ} \mathrm{F}$, at which the ultimate was $47,800 \mathrm{psi}$ and the yield was 37,000 psi.

The addition of $5 \% \mathrm{tin}$ also improved the properties of Ti-22.5Cb-10Al. (In all of these alloys the quaternary addition replaces titanium.) The alloy 
with tin was slightly more ductile at room temperature and had $80 \%$ higher yield strength at $1600^{\circ} \mathrm{F}$.

other examples may be found in the data to illustrate the beneficial effects of zirconium, hafnium, or tin additions, but those cited above should suffice. Because the elevated temperature strength-density ratio is an outstanding property in these alloys, a comparison with other alloys may be of interest. At $1600^{\circ} \mathrm{F}$, the ultimate tensile strength-density ratio of $\mathrm{Ti}-22.5 \mathrm{Cb}-$ 12.5Al-5Hf in the as-forged condition is 50\% higher than that of René 4l, and $35 \%$ higher than that of Udimet 700 . At $1800^{\circ} \mathrm{F}$, it is $150 \%$ higher than René 4 , $80 \%$ higher than Udimet 700, and higher than any of the refractory metal alloys of which we are aware. At $1800^{\circ} \mathrm{F}$, the as-forged ultimate tensile strengthdensity ratio of $T i-22.5 \mathrm{Cb}-15 \mathrm{Al}-1 / 22 \mathrm{r}(522,000)$ is about $75 \%$ higher than that of any other commercial or experimental alloy which has come to our attention.

It seems clear that quaternary alloys should receive additional attention-particularly those containing hafnium and zirconium.

4. A number of tensile tests at temperatures below $1200^{\circ} \mathrm{F}$ showed large dëvlations from normal strength-vs.-temperature and ductility-vs.-temperature relationships. Such effects might be caused by: (1) chemical inhomogeneity of the specimen stock; (2) structural transformations occurring during test; (3) structural inhomogeneity derived from the forging operation; or (4) combinations of these. Additional specimens of $\mathrm{Ti}-22.5 \mathrm{Cb}-12.5 \mathrm{Al}-1 \mathrm{Zr}$ and Ti22.5Cb-12.5Al-1Hf were prepared to obtain more information on this matter. In two out of three instances the anomalous behavior was not completely reproduced in duplicate tests. At $600^{\circ} \mathrm{F}$ the first specimen of Ti-22.5Cb-12.5Al-12r broke at 164,700 psi with no measurable yield or elongation and only $4 \%$ reduction in area. The duplicate had an ultimate strength of $166,300 \mathrm{psi}$, a yield of $148,000 \mathrm{psi}$, an elongation of $7.5 \%$ and a reduction in area of $5 \%$. A third specimen was treated $16 \mathrm{hr}$ at $1200^{\circ} \mathrm{F}$ and tested at $600^{\circ} \mathrm{F}$. It had an ultimate strength of $166,900 \mathrm{psi}$, a yield of $155,000 \mathrm{psi}$, an elongation of $4 \%$, and a reduction in area of $6 \%$. Thus, although the ultimate strength was nearly the same in each case, the ductility varied significantly.

The same alloy (Ti-22.5Cb-12.5Al-12r) had, at $1000^{\circ} \mathrm{F}$, an ultimate of $156,000 \mathrm{psi}$, a yield of $138,000 \mathrm{psi}$, an elongation of $6 \%$, and a reduction in area of $8 \%$. A duplicate specimen had an ultimate of 160,000 psi, a yielc of $140,000 \mathrm{psi}$, an elongation of $4.5 \%$, and a reduction in area of $14 \%$. This is acceptable reproducibility for work of this nature. A third specimen was treated $16 \mathrm{hr}$ at $1200^{\circ} \mathrm{F}$ and tested at $1000^{\circ} \mathrm{F}$. It had an ultimate of 173,300 psi, a yield of 168,000 psi, an elongation of $1 \%$, and a reducticn in area of $4 \%$, and was therefore significantly stronger and less ductile.

The first specimen of T1-22.5Cb-12.5Al-1hf tested at $100^{\circ} \mathrm{F}$ broke at 152,200 psi with no yield, no elongation, and $2 \%$ reduction in area. A duplicate had an ultimate of $126,400 \mathrm{psi}$, a yield of $95,000 \mathrm{psi}$, an elongation of $11 \%$, and a reduction in area of $15 \%$. A third specimen treated $16 \mathrm{hr}$ at $1600^{\circ} \mathrm{F}$ and tested at $400^{\circ} \mathrm{F}$ had an ultimate of 131,500 psi, a yield of $95,000 \mathrm{ps} 1$, an elongation of $8.5 \%$, and a reduction in area of $13 \%$. Note that the heat-treated specimen matched one of the as-forged specimens very well, while the other 
was much different. This indicated that the discrepancy is not due to transformation occurring during testing.

Because the aromalies referred to above have been observed only at low test temperatures and in as-forged material, it does not seem likely that chemical inhomogeneity is a principal cause, although there is no assurance that such inhomogeneity does not occasionally occur with alloys such as these, which are composed of reactive metals with widely different melting points and densities.

The anomalous results at lower temperatures are therefore thought to be caused by structural or "cold" work variations introduced during finish forging of the bar stock from which specimens were cut. Hore evidence is needed for a final resolution of the question. That evidence can come from additional tensile tests and also from chemical and metallographic analyses of specimens which have already been tested.

5. Two specimens tested at $-90^{\circ} \mathrm{F}$ in the as-forged condition had sufficient tensile dictility to suggest that there was not an abrupt transition to brittleness above this temperature. Ti-22.5Cb-12.5Al-12r had 169,100 psi ultimate, 151,000 psi $y i \in 1 d, 3 \%$ elongation, and $7 \%$ reduction in area. Ti-22.5Cb-12.5AlIHf had 135,000 psi ultimate, 119,000 psi yield, $3 \%$ elongation, and $7.5 \%$ reduction in area.

6. Ti-15Cb-1CAl could be rolled at ternperatures as low as $1600^{\circ} \mathrm{F}$. Asrolled sheet was not very bend ductile, but could be heat treated to pass bends as low as $2.5 t_{0}$ Comparable improvement in tensile ductility by heat treatment was not obtained, although tensile strength was greatly lowered. A large percentage of the tensile specimens failed in a brittle manner at the pin holes, which is a strong indication of notch sensitivity.

7. During stress-thermal exposure of $\mathrm{Ti}-15 \mathrm{Cb}-1 \mathrm{CAl}$, it was noted that this material (heat treated prior to exposure) had low creep strength at $1500^{\circ}, 1400^{\circ}$, and even $1200^{\circ} \mathrm{F}$. A load of 5,000 psi for $167 \mathrm{hr}$ at $1200^{\circ} \mathrm{F}$ caused about $2.3 \%$ creep. The initially low tensile ductility of the heat-treated Ti-15Cb-10Al sheet makes it difficult to derive significant information concerning stressthermal embrittlement. Perhaps the most important conclusion to be reached is that this alloy is simply too lean in columbium and aluminum to meet the requirements of this program.

0 . TI-17.5Cb-15Al can be finish rolled at a temperature of $1950^{\circ} \mathrm{F}$, but from the limited data avallable, $2000^{\circ} \mathrm{F}$ appears preferable. Sheet finish rolled at $1950^{\circ} \mathrm{F}$ passed the guided bend test at $R_{t}=14$, and failed at $R_{t}=9$. Sheet finished at $2000^{\circ} \mathrm{F}$ passed at $R_{t}=12$, but failed at $R_{t}=1 C$. Sheet finished at $2050^{\circ} \mathrm{F}$ failed a test at $R_{t}=20$.

The best bend ductility in heat-treated conditions was observed in material which had been finished at $195^{\circ} \mathrm{F}$ and treated for 90 min at $1600^{\circ} \mathrm{F}$, followed by air cooling; this passed a $4 t$ bend and failed $3 t$. One of three specimens from the same sheet which were treated $90 \mathrm{~min}$ at $1750^{\circ} \mathrm{F}$ passed a $6 \mathrm{t}$ bend and 
falled $4 \mathrm{t}$; the other two failed $10 \mathrm{t}$ and $10.5 \mathrm{t}$ tests. Such a large variation cannot be accounted for at this time, but should certainly receive further attention.

Other heat treatments which were tried did not improve bend ductility. However, none of these treatments included quenching.

Tensile ductility of the $\mathrm{Ti}-17.5 \mathrm{Cb}-15 \mathrm{Al}$ without heat treatment varied from 0 to $3.5 \%$ elongation. Two specimens finish rolled at $2000^{\circ} \mathrm{F}$ showed good duplication of tensile properties. Each had $3.5 \%$ elongation; ultimate tensile strengths were 139,000 and 140,000 psi; 0.15 yield strengths were 108,000 and $105,000 \mathrm{psi}$; and Young's moduli were 12.0 and $12.9 \mathrm{X} 10^{6} \mathrm{psi}$. In contrast to this, the sheet finish rolled at $1950^{\circ} \mathrm{F}$ had ultimate tensile strengths, in different specimens, of 104,$000 ; 112,000 ; 133,600$; and 148,000 psi, with moduli of $17.4,17.1,12.5$, and $15.6 \times 10^{6} \mathrm{psi}$ and ductilities of $0,0,3.5$, and 2.5\% elongation. Again, we do not know the cause of this variation, but the heat-treated specimens showed much better duplication, so that it is probable that $1950^{\circ} \mathrm{F}$ was a rather critical rolling temperature at which the temperature control was insufficient to ensure uniformity.

As with $\mathrm{Ti}-15 \mathrm{Cb}-1 \mathrm{CAl}$, there was a tendency for the Ti-17.5Cb-15Al tensile specimens to break through the pin holes, although the tendency was less pronounced in the latter alloy.

9. Stress-thermal exposures of Ti-17.5Cb-15Al were made with material previously heat treated at $1500^{\circ} \mathrm{F}$ or $1600^{\circ} \mathrm{F}$. For both heat treatments the creep strength was $1 \mathrm{cw}$, though much better than that of $\mathrm{TH}-15 \mathrm{Cb}-10 \mathrm{Al}$. Despite the unexpectedly large amount of creep, the stress-thermal exposures did not cause embrittlement; they did, however further lower the strength, which had already been reduced by the prior heat treatments. Two specimens, the first stressed at 7,500 psi and $1500^{\circ} \mathrm{F}$ for $167 \mathrm{hr}$ ( $5 \%$ creep), the second stressed at $10,000 \mathrm{psi}$ and $1500^{\circ} \mathrm{F}$ for $170 \mathrm{hr}$ (10\% creep), had $405 \%$ elongation in subsequent room-temperature tensile test. This may be compared with two specimens in the same condition of heat treatment ( $6 \mathrm{hr}-1500^{\circ} \mathrm{F}-\mathrm{AC}$ ) tested without the stress-thermal exposure; of these, one had $3.5 \%$ elongation, the other $5 \%$.

Similarly, a third specimen treated $90 \mathrm{~min}-1600^{\circ} \mathrm{F}-\mathrm{AC}$ and stressed at $5,000 \mathrm{psi}$ and $1500^{\circ} \mathrm{F}$ for $167 \mathrm{hr}$ ( $\mathrm{L}_{.} 6 \%$ creep) had an elongation of $3.3 \%$ in subsequent tensile test. The corresponding specimen without stress-thermal exposure had an elongation of $3.5 \%$, but broke outside the gage length.

10. Among heat-treated specimens of $\mathrm{Ti}-17.5 \mathrm{Cb}-15 \mathrm{Al}$, the best roomtenperature tensile properties were found in a specimen heat treated 2 lhr $1400^{\circ} \mathrm{F}-\mathrm{AC}$. This had a $0.01 \%$ yield of $74,700 \mathrm{psi}$, an $0.1 \%$ yield of 77,000 psi, an $0.2 \%$ yield of 77,600 psi, an ultimate of 102,000 psi, a modulus of $12.6 \mathrm{X}$ $10^{6} \mathrm{psi}$, and an elcrgation of $5.5^{\circ}$. It had been finish rolled at $2000^{\circ} \mathrm{F}$.

11. The brittleness of welds in Ti-15Cb-10AI and Ti-17.5Cb-15AI indicates lack of weldability. However, more work is necessary to find out whether this shortcoming is actually shared by more highly alloyed and more complex compositions. 


\section{RECOMMNDATIONS}

From a consideration of the facts discussed above, it is recommended that additional exploratory work should be undertaken during the next year. This should be directed toward alloys of high columbium and aluminum content, including those containing quaternary additions of hafnium and zirconium. At the same time, additional investigation should be made of the following alloys:

Ti-22. $5 \mathrm{Cb}-12.5 \mathrm{Al}-5 \mathrm{HF}$

$\mathrm{TI}-22.5 \mathrm{Cb}-12.5 \mathrm{Al}-1 \mathrm{Hf}$

Ti-22. $5 \mathrm{Cb}-12.5 \mathrm{Al}-1 \mathrm{Zr}$

Ti-22.5Cb-12.5Al-5Sn

$\mathrm{Ti}-22.5 \mathrm{Cb}-15 \mathrm{~A} 1-1 \mathrm{Sn}$

Ti-22.5Cb-15A1-0.52r

For these, the following should be determined: (1) short-time tensile strength at higher temperatures than have been tried so far; (2) effects of heat treatment on structure and tensile properties at various temperatures; (3) effects of forging and rolling temperature on tensile properties; and (4) stressrupture strengths.

It is recognized that the properties of notch sensitivity, weldability, and creep strength will require a great deal more attention, but it is felt that major efforts in these areas can best be undertaken when more information of a general nature has been accumulated.

\section{STMMARY}

Alloy additions of hafnium, tin, or zirconium to the base alloys TH$22.5 \mathrm{Cb}-(7.5-15 \mathrm{Al})$ were found to have favorable effects on oxidation resistance, high-temperature strength, and ductility. In some instances the improvement of high-temperature strength was concomitant with greater ductility at room temperature. Several alloys showed superlative strengthdensity ratios at temperatures up to $1800^{\circ} \overrightarrow{\mathrm{F}}$, the highest temperature investigated.

The properties observed in four high-purity alloys were similar to those of the same alloys prepared with sponge titarium.

Sheet prepared from two ternary alloys showed strong response to heat treatment. One of these--Ti-15Cb-10Al-1s now considered to be too lean in columbium and alunimum to be serviceable in the temperature range with which this program is concerned. The other--Ti-17.5Cb-15Al--showed low creep strength in two heat-treated conditions, was not embrittled by stress-thermal exposure at $1500^{\circ} \mathrm{F}$, was not weldable, and appeared to be notch sensitive。 one heat-treated specimen passed a $4 \mathrm{t}$ guided bend test; another passed $6 \mathrm{t}$. 
Analysis of the information obtained thus far leads to two recommendations: (1) further exploratory work should be directed toward alloys of high columbium and aluminum content, including those containing hafnium and zirconium; and (2) additional investigation should be made of six alloys selected from those prepared during the past year. 
TABLE I

ANALYSES OF COLUMBIUM INGOTS

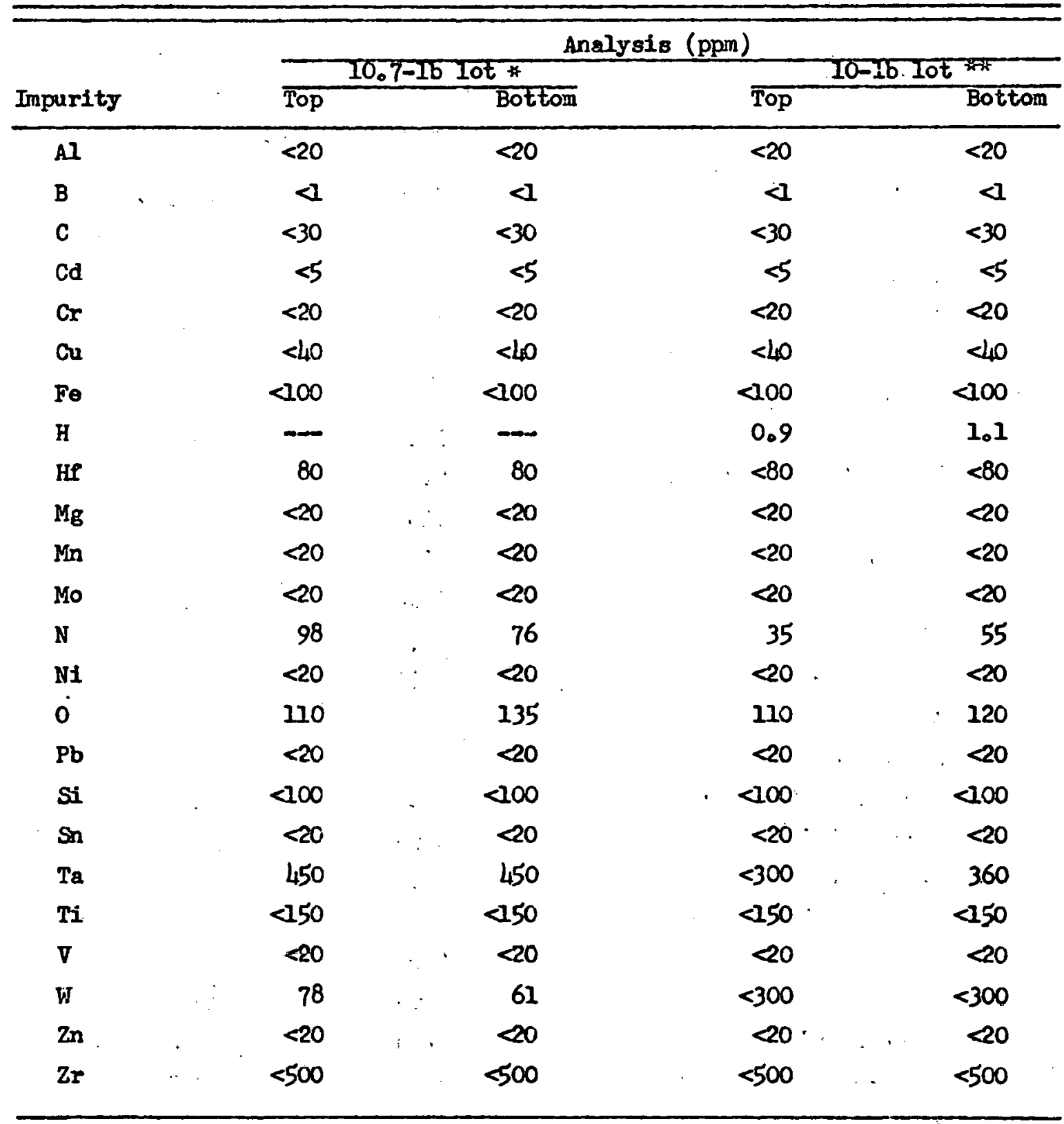

* Hardness: 55.1-71.5 BHN; Average: 64

** Hardness: 54.1-65.5 BHN; Average: 59 
TABLE II

FORGING TEMPERATURES

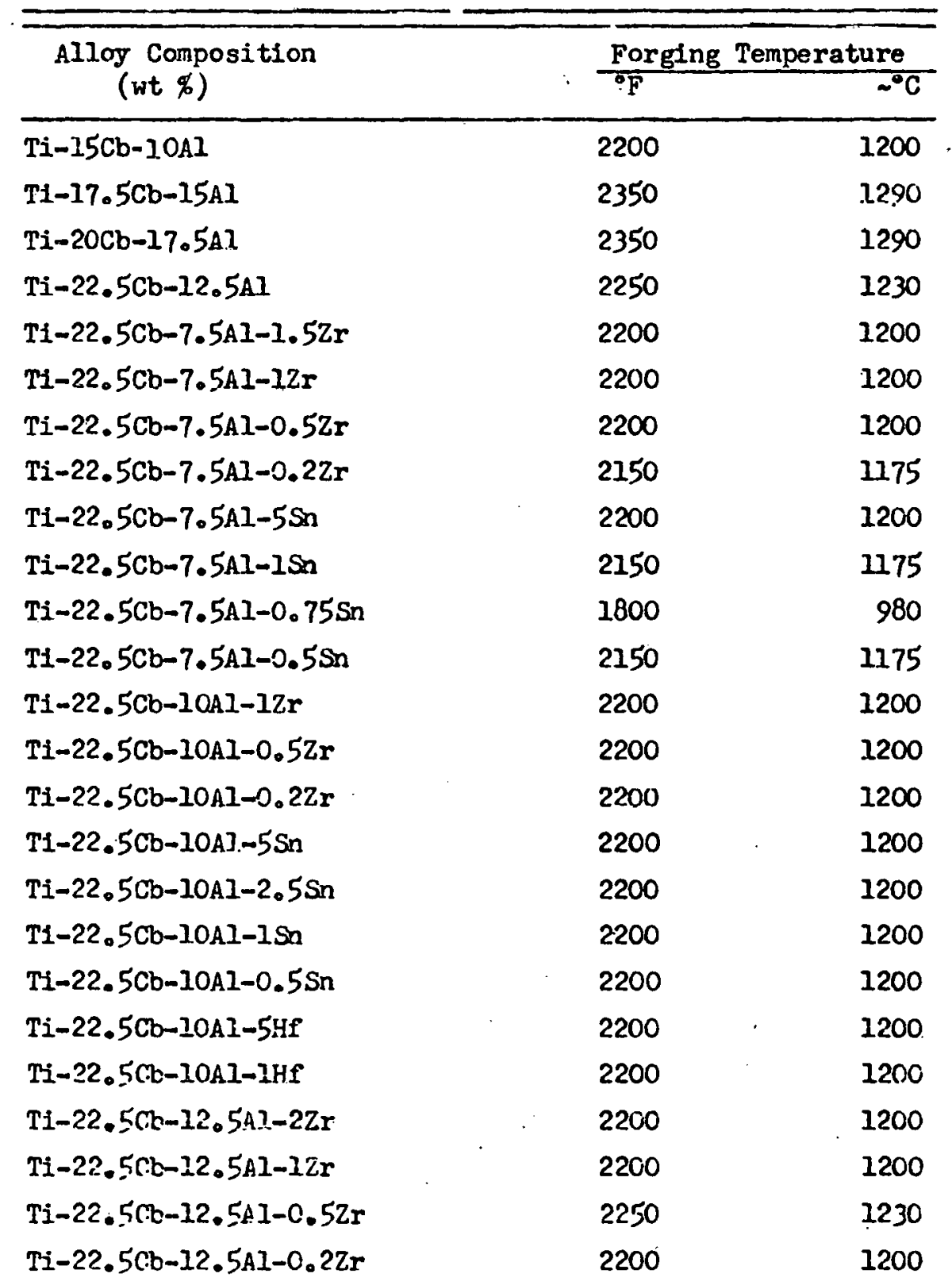


TABLE II (contimed)

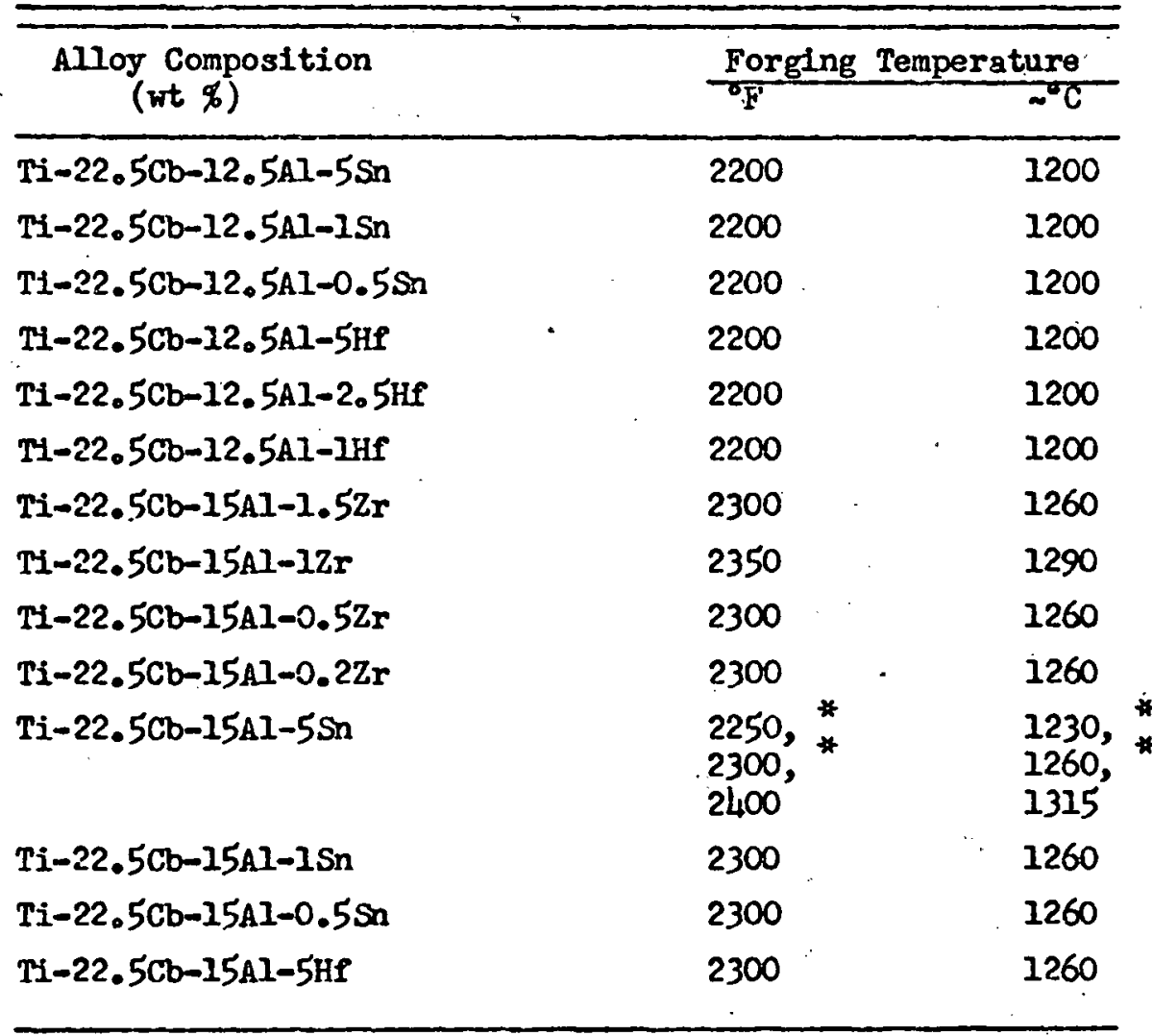

* Did not forge at this temperature. 
TABLE III

DENSITIES OF FORGED ALLOYS

\begin{tabular}{|c|c|c|c|}
\hline \multirow{2}{*}{$\begin{array}{l}\text { Alloy Composition } \\
\text { (wt } \%)\end{array}$} & \multicolumn{3}{|c|}{ Density } \\
\hline & $\mathrm{g} / \mathrm{cm}^{3}$ & 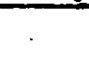 & $1 b /$ in $^{3}$ \\
\hline $\mathrm{Ti}-15 \mathrm{Cb}-10 \mathrm{AI}$ & 4.59 & & 0.166 \\
\hline $\mathrm{Ti}-17.5 \mathrm{Cb}-15 \mathrm{Al}$ & 4.56 & & 0.265 \\
\hline $\mathrm{T} 1-20 \mathrm{Cb}-17.5 \mathrm{AI}$ & +5.54 & $\cdot$ & 0.164 \\
\hline $\mathrm{T} 1-22.5 \mathrm{Cb}-12.5 \mathrm{Al}$ & 4.72 & & 0.170 \\
\hline $\mathrm{Ti}-22.5 \mathrm{Cb}-7.5 \mathrm{Al}-1.5 \mathrm{Zr}$ & 4.86 & & 0.175 \\
\hline $\mathrm{Ti}-22.5 \mathrm{Cb}-7.5 \mathrm{Al}-1 \mathrm{Zr}$ & 4.87 & & 0.176 \\
\hline $\mathrm{Ti}-22.5 \mathrm{Cb}-7.5 \mathrm{Al}-0.5 \mathrm{Zr}$ & 4.85 & & 0.275 \\
\hline $\mathrm{T} 1-22.5 \mathrm{Cb}-7.5 \mathrm{Al}-0.2 \mathrm{Zr}$ & 4.86 & & 0.175 \\
\hline $\mathrm{Ti}-22.5 \mathrm{Cb}-7.5 \mathrm{Al}-5 \mathrm{Sn}$ & 5.01 & & 0.181 \\
\hline $\mathrm{Ti} \div 22.5 \mathrm{Cb}-7.5 \mathrm{Al}-1 \mathrm{Sn}$ & 4.88 & & 0.276 \\
\hline $\mathrm{Ti}-22.5 \mathrm{Cb}-7.5 \mathrm{Al}-0.75 \mathrm{Sn}$ & 4.56 & & 0.175 \\
\hline$T i-22.5 \mathrm{Cb}-7.5 \mathrm{Al}-0.5 \mathrm{Sn}$ & 4.86 & & 0.175 \\
\hline $\mathrm{Ti}-22.5 \mathrm{Cb}-10 \mathrm{Al}-1 \mathrm{Zr}$ & 4.82 & & 0.174 \\
\hline $\mathrm{Ti}-22.5 \mathrm{Cb}-10 \mathrm{Al}-0.5 \mathrm{Zr}$ & 4.81 & & 0.174 \\
\hline $\mathrm{Ti}-22.5 \mathrm{Cb}-10 \mathrm{Al}-0.2 \mathrm{Zr}$ & 4.80 & & 0.173 \\
\hline $\mathrm{Ti}-22.5 \mathrm{Cb}-10 \mathrm{Al}-5 \mathrm{Sn}$ & 4096 & & 0.179 \\
\hline $\mathrm{Ti}-22.5 \mathrm{Cb}-10 \mathrm{Al}-2.5 \mathrm{Sh}$ & 4.85 & & 0.175 \\
\hline $\mathrm{Ti}-22.5 \mathrm{Cb}-10 \mathrm{Al}-1 \mathrm{Sn}$ & 4.82 & & 0.174 \\
\hline $\mathrm{Ti}-22.5 \mathrm{Cb}-10 \mathrm{Al}-0.5 \mathrm{Sn}$ & 4.78 & & 0.172 \\
\hline $\mathrm{Ti}-22.5 \mathrm{Cb}-10 \mathrm{Al}-5 \mathrm{Hf}$ & 4.93 & & 0.178 \\
\hline $\mathrm{Ti}-22.5 \mathrm{Cb}-10 \mathrm{Al}-\mathrm{IHf}$ & 4.82 & & 0.174 \\
\hline $\mathrm{Ti}-22.5 \mathrm{Cb}-12.5 \mathrm{Al}-2 \mathrm{Zr}$ & 4.75 & & 0.172 \\
\hline $\mathrm{Ti}-22.5 \mathrm{Cb}-12.5 \mathrm{Al}-1 \mathrm{Zr}$ & 4.76 & & 0.172 \\
\hline $\mathrm{Ti}-22.5 \mathrm{Cb}-12.5 \mathrm{Al}-0.5 \mathrm{Zr}$ & 4.75 & & 0.172 \\
\hline $\mathrm{Ti}-22.5 \mathrm{Cb}-12.5 \mathrm{Al}-\mathrm{C} .2 \mathrm{Zr}$ & 4.72 & & 0.170 \\
\hline $\mathrm{Ti}-22.5 \mathrm{Cb}-12.5 \mathrm{Al}-5 \mathrm{Sn}$ & 4.88 & & 0.176 \\
\hline $\mathrm{Ti}-22.5 \mathrm{Cb}-12.5 \mathrm{Al}-1 \mathrm{Sn}$ & 4.75 & & 0.172 \\
\hline
\end{tabular}


TABLE I.II (continued)

\begin{tabular}{|c|c|c|}
\hline \multirow{2}{*}{$\begin{array}{c}\text { Alloy Composition } \\
\text { (wt } \% \text { ) }\end{array}$} & \multicolumn{2}{|c|}{ Density } \\
\hline & $\mathrm{g} / \mathrm{cm}^{3}$ & $1 b /$ in $^{3}$ \\
\hline $\mathrm{Ti}-22.5 \mathrm{Cb}-12.5 \mathrm{Al}-0.5 \mathrm{Sn}$ & 4.74 & 0.171 \\
\hline Ti-22.5Cb-22.5AI-5Hf & 4.90 & 0.177 \\
\hline $\mathrm{Ti}-22.5 \mathrm{Cb}-12.5 \mathrm{Al}-2.5 \mathrm{Hf}$ & 4.80 & 0.173 \\
\hline $\mathrm{Ti}-22.5 \mathrm{Cb}-12.5 \mathrm{Al}-\mathrm{HH}$ & 4.78 & 0.173 \\
\hline $\mathrm{Ti}-22.5 \mathrm{Cb}-15 \mathrm{Al}-1.52 \mathrm{r}$ & 4.69 & $0: 169$ \\
\hline $\mathrm{Ti}-22.5 \mathrm{Cb}-15 \mathrm{Al}-1 \mathrm{Zr}$ & 4.70 & 0.170 \\
\hline $\mathrm{Ti}-22.5 \mathrm{cb}-15 \mathrm{Al}-0.5 \mathrm{Zr}$ & 4.70 & 0.170 \\
\hline $\mathrm{Ti}-22.5 \mathrm{Cb}-15 \mathrm{Al}-\mathrm{C} .2 . \mathrm{Zr}$ & 4.66 & 0.168 \\
\hline $\mathrm{T} 1-22.5 \mathrm{Cb}-15 \mathrm{Al}-5 \mathrm{Sn}$ & 4.82 & 0.3 .74 \\
\hline$T i-22.5 \mathrm{Cb}-15 \mathrm{Al}-1 \mathrm{Sn}$ & 4.71 & 0.1 .70 \\
\hline $\mathrm{Ti}-22.5 \mathrm{cb}-25 \mathrm{Al}-\mathrm{C} .5 \mathrm{Sn}$ & 4.68 & 0.169 \\
\hline $\mathrm{Ti}-22.5 \mathrm{Cb}-15 \mathrm{Al}-5 \mathrm{Hf}$ & 4.82 & 0.174 \\
\hline
\end{tabular}


TABIE IV

OXIDATION OF TITANIUM ALLOYS

EXPOSED TO STILL AIR AT $1830^{\circ} \mathrm{F}\left(1000^{\circ} \mathrm{C}\right)$ FOR 84 HOURS

\begin{tabular}{|c|c|c|c|}
\hline $\begin{array}{c}\text { Alloy Composition } \\
\text { (wt \%) }\end{array}$ & $\begin{array}{l}\text { Spocimen } \\
\text { Weight } \\
\text { (g) }\end{array}$ & $\begin{array}{l}\text { Weight } \\
\text { Gain } \\
\text { (g) }\end{array}$ & $\begin{array}{l}\text { Depth of } \\
\text { Oxidation } \\
\text { (in.) }\end{array}$ \\
\hline $\mathrm{Ti}-22.5 \mathrm{Cb}-7.5 \mathrm{Al}-0.52 \mathrm{r}$ & 2.7958 & 0.032 & 0.003 \\
\hline Ti-22.5Cb-10AI-IHf & 2.7407 & 0.031 & 0.002 \\
\hline $\mathrm{T} 1-22.5 \mathrm{Cb}-12.5 \mathrm{Al}-1 \mathrm{Zr}$ & 2.8450 & 0.02 .4 & 0.001 \\
\hline $\mathrm{Ti}-22.5 \mathrm{Cb}-12.5 \mathrm{Al}-1 \mathrm{Hf}$ & $2.8331 !$ & 0.032 & 0.002 \\
\hline $\mathrm{Ti}-22.5 \mathrm{Cb}-12.5 \mathrm{Al}-5 \mathrm{HP}$ & 2.9837 & 0.027 & $<0.001$ \\
\hline $\mathrm{Ti}-22.5 \mathrm{Cb}-15 \mathrm{Al}-\mathrm{C} .5 \mathrm{Zr}$ & 2.8073 & 0.027 & 0.001 \\
\hline $\mathrm{T} i-22.5 \mathrm{Cb}-15 \mathrm{~A} 1-2 \mathrm{Sn}$ & 2.8015 & 0.022 & $<0.001$ \\
\hline $\mathrm{T} 3-22.5 \mathrm{Cb}-12.5 \mathrm{Al}$ & 2.6019 & 0.036 & $<0.001$ \\
\hline
\end{tabular}


TABLE V

OXIDATION OF TITANIUM ALLOYS EXPOSED TO STILL AIR AT $1830^{\circ} \mathrm{F}\left(1000^{\circ} \mathrm{C}\right)$ FOR 100 HOURS

\begin{tabular}{|c|c|c|c|}
\hline $\begin{array}{c}\text { Alloy Composition } \\
\text { (wt } \%)\end{array}$ & $\begin{array}{c}\text { Specimen } \\
\text { Weight } \\
\text { (g)* }\end{array}$ & $\begin{array}{c}\text { Weight } \\
\text { Gain } \\
\text { (g) }\end{array}$ & $\begin{array}{l}\text { Depth } \\
\text { of } \\
\text { Oxidation } \\
\text { (in.) }\end{array}$ \\
\hline TI-22.5Cb-7.5Al-1.5Zr & 4.3912 & 0.040 & $0.001^{+}$ \\
\hline $\mathrm{Ti}-22.5 \mathrm{Cb}-7.5 \mathrm{Al}-0.75 \mathrm{SA}$ & 4.4732 & 0.052 & 0.001 \\
\hline $\mathrm{Ti}-22.5 \mathrm{Cb}-10 \mathrm{~A} 1-2.5 \mathrm{Sn}$ & 4.0925 & 0.035 & $<0.001$ \\
\hline $\mathrm{Ti}-22.5 \mathrm{Cb}-10 \mathrm{Al}-0.5 \mathrm{Sn}$ & 4.3296 & 0.046 & 0.002 \\
\hline $\mathrm{Ti}-22.5 \mathrm{Cb}-10 \mathrm{Al}-5 \mathrm{HP}$ & $40 !+445$ & 0.023 & $<0.001^{+}$ \\
\hline $\mathrm{Ti}-22.5 \mathrm{Cb}-12.5 \mathrm{Al}$ & 4.2824 & 0.043 & 0.001 \\
\hline $\mathrm{Ti}-22.5 \mathrm{Cb}-12.5 \mathrm{Al}-2 \mathrm{Zr}$ & 4.2803 & 0.036 & $<0.001$ \\
\hline $\mathrm{Ti}-22.5 \mathrm{Cb}-12.5 \mathrm{Al}-1 \mathrm{Zr}$ & 4.2558 & 0.021 & $<0.001^{+}$ \\
\hline $\mathrm{Ti}-22.5 \mathrm{Cb}-12.5 \mathrm{Al}-0.2 \mathrm{Zr}$ & 4.2777 & 0.036 & $<0.001^{+}$ \\
\hline $\mathrm{Ti}-22.5 \mathrm{Cb} 12.5 \mathrm{AZ}-1 \mathrm{Sn}$ & 4.3357 & 0.037 & $<0.001$ \\
\hline$T i-22.5 \mathrm{Cb}-12.5 \mathrm{Al}-0.5 \mathrm{Sn}$ & 4.2313 & 0.045 & $<0.001$ \\
\hline $\mathrm{Ti}-22.5 \mathrm{Cb}-12.5 \mathrm{Al}-2.5 \mathrm{HP}$ & 4.3463 & 0.031 & $<0.001^{+}$ \\
\hline $\mathrm{Ti}-22.5 \mathrm{Cb}-12.5 \mathrm{Al}-1 \mathrm{Hf}$ (A) & 4.1496 & 0.033 & $<0.001$ \\
\hline $\mathrm{Ti}-22.5 \mathrm{Cb}-12.5 \mathrm{Al}-1 \mathrm{HP}$ (B) & 4. 2858 & 0.024 & $<0.001^{+}$ \\
\hline $\mathrm{Ti}-22.5 \mathrm{Cb}-15 \mathrm{Al}-1.5 \mathrm{Zr}$ & 4. 2382 & 0.030 & $<0.001$ \\
\hline $\mathrm{Ti}-22.5 \mathrm{Cb}-15 \mathrm{Al}-0.2 \mathrm{Zr}$ & 4.1773 & 0.034 & $<0.001$ \\
\hline $\mathrm{T} i-22.5 \mathrm{Cb}-15 \mathrm{Al}-5 \mathrm{Sn}$ & 4.3830 & 0.032 & $<0.001$ \\
\hline $\mathrm{Ti}-22.5 \mathrm{Cb}-15 \mathrm{Al}-0.5 \mathrm{Sn}$ & 4.2098 & 0.026 & $<0.001$ \\
\hline $\mathrm{TI}-22.5 \mathrm{Cb}-15 \mathrm{Al}-5 \mathrm{HP}$ & 4.0566 & 0.029 & $<0.001$ \\
\hline$T I-20 \mathrm{Cb}-17.5 \mathrm{AI}$ & 4.0945 & 0.037 & $<0.001$ \\
\hline $\mathrm{Ti}-17.5 \mathrm{Cb}-15 \mathrm{Al}$ & 4. 2070 & 0.035 & $<0.001$ \\
\hline Ti-15Cb-10AI & 4.1698 & 0.072 & 0.002 \\
\hline
\end{tabular}

* Area of these specimens $4.8 \mathrm{~cm}^{2}$.

+ Oxide did not spall on cooling. 
TABLE VI

SHORT-TIME TENSTLE DATA. FOR TITANTUM ALLOYS

\begin{tabular}{|c|c|c|c|c|c|}
\hline $\begin{array}{c}\text { Alloy Composition } \\
(\text { wt \&) }\end{array}$ & $\begin{array}{l}\text { Test } \\
\text { Temp } \\
\left({ }^{\circ} F\right)\end{array}$ & $\begin{array}{l}\text { UTS } \\
\text { (psi) }\end{array}$ & $\begin{array}{l}0.2 \% \text { YS } \\
\text { (psi) }\end{array}$ & $\begin{array}{l}\% \text { El. in } \\
0.7 \text { in. }\end{array}$ & $\% R A$ \\
\hline $\begin{array}{l}\text { Ti-15Cb-10A1 } \\
\text { (H1gh Purity) }\end{array}$ & $\begin{array}{l}\mathrm{RT} \\
800 \\
1200 \\
1400 \\
1600\end{array}$ & $\begin{array}{r}181,900 \\
142,700 \\
121,800 \\
78,000 \\
32,600\end{array}$ & $\begin{array}{r}170,000 \\
127,000 \\
108,000 \\
69,000 \\
26,000\end{array}$ & $\begin{array}{l}1.5 \\
10 \\
19 \\
12 \\
26\end{array}$ & $\begin{array}{r}5 \\
23 \\
62 \\
22 \\
46\end{array}$ \\
\hline $\begin{array}{l}\text { Ti-17.5Cb-15Al } \\
\text { (High Purity) }\end{array}$ & $\begin{array}{c}R T \\
1000 \\
1200 \\
1 L 00 \\
1600\end{array}$ & $\begin{array}{r}123,000 \\
122,000 \\
129,600 \\
70,300 \\
61,000\end{array}$ & $\begin{array}{r}88,000 \\
103,000 \\
50,000 \\
52,000\end{array}$ & $\begin{array}{r}-- \\
11 \\
8 \\
36 \\
67\end{array}$ & $\begin{array}{r}3 \\
14 \\
14 \\
45 \\
>95\end{array}$ \\
\hline $\begin{array}{l}\text { Ti-20Cb-17.5Al } \\
\text { (High Purity) }\end{array}$ & $\begin{array}{c}\mathrm{RT} \\
1200 \\
1400 \\
1600\end{array}$ & $\begin{array}{l}129,900 \\
185,000 \\
135,500 \\
103,200\end{array}$ & $\begin{array}{c}164,000 \\
98,000\end{array}$ & $\begin{array}{l}-\overline{2.5} \\
-- \\
2.5\end{array}$ & $\begin{array}{l}1 \\
3.5 \\
2 \\
3\end{array}$ \\
\hline $\begin{array}{l}\text { Ti-22.5Cb-12.5Al } \\
\text { (High Purity) }\end{array}$ & $\begin{array}{c}\mathrm{RT} \\
12.00 \\
1400 \\
1600\end{array}$ & $\begin{array}{r}153,000 \\
120,100 \\
74,700 \\
58,300\end{array}$ & $\begin{array}{r}135,000 \\
105,000 \\
65,000 \\
51,000\end{array}$ & $\begin{array}{l}3 \\
14 \\
8 \\
9.5\end{array}$ & $\begin{array}{l}2.5 \\
35 \\
28 \\
15\end{array}$ \\
\hline $\mathrm{T} 1-22.5 \mathrm{Cb}-7.5 \mathrm{Al}-1.5 \mathrm{Zr}$ & $\begin{array}{l}R T \\
800 \\
1200 \\
1100 \\
1600\end{array}$ & $\begin{array}{r}176,100 \\
114,800 \\
115,300 \\
78,000 \\
22,800\end{array}$ & $\begin{array}{r}111,-000 \\
104,000 \\
71,000 \\
21,000\end{array}$ & $\begin{array}{l}- \\
3 \\
4.5 \\
15 \\
131\end{array}$ & $\begin{array}{r}2 \\
11 \\
8 \\
24 \\
>90\end{array}$ \\
\hline $\mathrm{TI}-22.5 \mathrm{Cb}-7.5 \mathrm{Al}-1 \mathrm{Zr}$ & $\begin{array}{l}\text { RT } \\
800 \\
1200 \\
1400 \\
1600\end{array}$ & $\begin{array}{r}164,900 \\
157,000 \\
144,900 \\
142,700 \\
65,300\end{array}$ & $\begin{array}{r}162,000 \\
146,000 \\
136,000 \\
116,000 \\
54,000\end{array}$ & $\begin{array}{r}3 \\
4 \\
4 \\
10 \\
20\end{array}$ & $\begin{array}{r}1 \\
4 \\
7 \\
15 \\
52\end{array}$ \\
\hline $\mathrm{Ti}-22.5 \mathrm{Cb}-7.5 \mathrm{Al}-\mathrm{C} .5 \mathrm{Zr}$ & $\begin{array}{c}\text { RT } \\
1200 \\
1400 \\
1600\end{array}$ & $\begin{array}{r}124,800 \\
153,800 \\
121,600 \\
61,300\end{array}$ & $\begin{array}{r}118,000 \\
114,000 \\
94,000 \\
51,000\end{array}$ & $\begin{array}{l}7 \\
1 \\
10 \\
30\end{array}$ & $\begin{array}{r}9 \\
3 \\
21 \\
62\end{array}$ \\
\hline
\end{tabular}


TABLE VI (continued)

\begin{tabular}{|c|c|c|c|c|c|}
\hline $\begin{array}{l}\text { Alloy Composition } \\
\text { (wt \%) }\end{array}$ & $\begin{array}{l}\text { Test } \\
\text { Temp } \\
\left({ }^{\circ} \mathrm{F}\right)\end{array}$ & $\begin{array}{l}\text { UTS } \\
\text { (psi) }\end{array}$ & $\begin{array}{r}0.2 \% \text { YS } \\
\text { (psi) }\end{array}$ & $\begin{array}{c}\% \mathrm{El} \text {. in } \\
0.7 \mathrm{in} .\end{array}$ & \& $\mathrm{RA}$ \\
\hline $\mathrm{Ti}-22.5 \mathrm{Cb}-7.5 \mathrm{Al}-0.2 \mathrm{Zr}$ & $\begin{array}{c}\mathrm{RT} \\
800 \\
1200 \\
1400 \\
1600\end{array}$ & $\begin{array}{r}134,000 \\
169,400 \\
151,500 \\
134,000 \\
64,600\end{array}$ & $\begin{array}{c}127,000 \\
138,000 \\
23,000 \\
50,000\end{array}$ & $\begin{array}{r}7 \\
0 \\
1 \\
15 \\
21\end{array}$ & $\begin{array}{r}15 \\
0 \\
8 \\
39 \\
50\end{array}$ \\
\hline $\mathrm{T} 1-22.5 \mathrm{Cb}-7.5 \mathrm{Al}-5 \mathrm{Sn}$ & $\begin{array}{c}\text { RT } \\
1200 \\
1400 \\
1600 \\
1800\end{array}$ & $\begin{array}{r}155,200 \\
171,600 \\
169,400 \\
85,600 \\
31,800\end{array}$ & $\begin{array}{r}158,000 \\
144,000 \\
76,000 \\
28,000\end{array}$ & $\begin{array}{r}0 \\
1 \\
2 \\
0 \\
17\end{array}$ & $\begin{array}{r}0 \\
7 \\
3 \\
2 \\
36\end{array}$ \\
\hline $\mathrm{T} 1-22.5 \mathrm{Cb}-7.5 \mathrm{Al}-1 \mathrm{Sn}$ & $\begin{array}{l}\mathrm{RT} \\
800 \\
1200 \\
1400 \\
1600\end{array}$ & $\begin{array}{r}131,500 \\
98,800 \\
171,600 \\
137,000 \\
68,500\end{array}$ & $\begin{array}{r}129,000 \\
76,000 \\
160,000 \\
110,000 \\
56,000\end{array}$ & $\begin{array}{r}6 \\
8 \\
1 \\
18 \\
8\end{array}$ & $\begin{array}{r}6 \\
35 \\
6 \\
47 \\
16\end{array}$ \\
\hline $\mathrm{T} 1-22.5 \mathrm{Cb}-7.5 \mathrm{Al}-0.75 \mathrm{Sn}$ & $\begin{array}{c}\mathrm{RT} \\
800 \\
1200 \\
1600\end{array}$ & $\begin{array}{r}211,700 \\
17 \%, 400 \\
138,900 \\
27,700\end{array}$ & $\begin{array}{r}193,000 \\
168,000 \\
132,000 \\
24,000\end{array}$ & $\begin{array}{l}1.5 \\
1.5 \\
9.5 \\
60\end{array}$ & $\begin{array}{rl} & 2.5 \\
5 & 24 \\
>90\end{array}$ \\
\hline $\mathrm{Ti}-22.5 \mathrm{Cb}-7.5 \mathrm{Al}-0.5 \mathrm{Sn}$ & $\begin{array}{c}R T \\
800 \\
1200 \\
1400 \\
1600\end{array}$ & $\begin{array}{r}176,000 \\
173,800 \\
118,600 \\
129,600 \\
61,500\end{array}$ & $\begin{array}{r}167,000 \\
105,000 \\
114,000 \\
52,000\end{array}$ & $\begin{array}{r}0 \\
1 \\
10 \\
2 \\
20\end{array}$ & $\begin{array}{r}0 \\
3 \\
15 \\
9 \\
41\end{array}$ \\
\hline $\mathrm{T} 1-22.5 \mathrm{Cb}-10 \mathrm{Al}-1 \mathrm{Zr}$ & $\begin{array}{c}\mathrm{RT} \\
1200 \\
1400 \\
1600 \\
1800\end{array}$ & $\begin{array}{r}769,100 \\
140,500 \\
158,200 \\
87,800 \\
30,700\end{array}$ & $\begin{array}{r}127,000 \\
139,000 \\
76,000 \\
25,000\end{array}$ & $\begin{array}{r}n \\
8 \\
18 \\
11 \\
55\end{array}$ & $\begin{array}{r}1 \\
26 \\
30 \\
30 \\
>95\end{array}$ \\
\hline $\mathrm{Ti}-22.5 \mathrm{Cb}-10 \mathrm{Al}-0.5 \mathrm{Zr}$ & $\begin{array}{c}\mathrm{RT} \\
1200 \\
1400 \\
1600\end{array}$ & $\begin{array}{r}149,300 \\
136,000 \\
144,100 \\
90,600\end{array}$ & $\begin{array}{r}147,000 \\
118,000 \\
123,000 \\
76,000\end{array}$ & $\begin{array}{r}3 \\
8 \\
10 \\
10\end{array}$ & $\begin{array}{l}5 \\
30 \\
27 \\
18\end{array}$ \\
\hline
\end{tabular}


TABLF, VI (continued)

\begin{tabular}{|c|c|c|c|c|c|}
\hline $\begin{array}{l}\text { Alloy Composition } \\
\text { (wt } \mathscr{\text { g }} \text { ) }\end{array}$ & $\begin{array}{l}\text { Test } \\
\text { Teinp } \\
\left({ }^{\circ} \mathrm{F}\right)\end{array}$ & $\begin{array}{l}\text { UTS } \\
\text { (psi) }\end{array}$ & $\begin{array}{r}0.2 \% \text { YS } \\
\text { (psi). }\end{array}$ & $\begin{array}{l}\% \text { E]. in } \\
0.7 \mathrm{in} .\end{array}$ & $\% R A$ \\
\hline $\mathrm{Ti}-22.5 \mathrm{Cb}-10 \mathrm{Al}-\mathrm{C} .22 \mathrm{r}$ & $\begin{array}{l}R T \\
800 \\
1200 \\
1400 \\
1600\end{array}$ & $\begin{array}{r}128,300 \\
176,200 \\
118,600 \\
149,300 \\
84,800\end{array}$ & $\begin{array}{r}117,000 \\
169,000 \\
103,000 \\
129,000 \\
71,000\end{array}$ & $\begin{array}{r}3 \\
1 \\
4 \\
22 \\
22\end{array}$ & $\begin{array}{r}5 \\
3 \\
6 \\
74 \\
4.5\end{array}$ \\
\hline$T i-22.5 C b-10 A I-5 S n$ & $\begin{array}{c}\text { RT } \\
800 \\
1200 \\
1400 \\
1600\end{array}$ & $\begin{array}{r}149,300 \\
113,200 \\
147,900 \\
114,200 \\
80,200\end{array}$ & $\begin{array}{r}140,000 \\
87,000 \\
132,000 \\
105,000 \\
69,000\end{array}$ & $\begin{array}{r}3 \\
12 \\
7 \\
17 \\
47\end{array}$ & $\begin{array}{r}5 \\
27 \\
21 \\
16 \\
>95\end{array}$ \\
\hline $\mathrm{Ti}-22.5 \mathrm{Cb}-10 \mathrm{Al}-2.5 \mathrm{Sn}$ & $\begin{array}{c}R T \\
800 \\
1000 \\
1200 \\
1600\end{array}$ & $\begin{array}{r}171,300 \\
156,300 \\
179,500 \\
131,500 \\
45,700\end{array}$ & $\begin{array}{r}169,000 \\
153,000 \\
168,000 \\
118,000 \\
39,000\end{array}$ & $\begin{array}{l}1.5 \\
3 \\
4.5 \\
9.5 \\
15\end{array}$ & $\begin{array}{r}5 \\
8 \\
8 \\
27 \\
21\end{array}$ \\
\hline $\mathrm{Ti}-22.5 \mathrm{Cb}-10 \mathrm{Al}-1 \mathrm{Sn}$ & $\begin{array}{c}\mathrm{RT} \\
1200 \\
1100 \\
1600 \\
1800\end{array}$ & $\begin{array}{r}144,900 \\
173,500 \\
151,500 \\
78,000 \\
37,900\end{array}$ & $\begin{array}{r}140,000 \\
164,000 \\
136,000 \\
63,000 \\
32,000\end{array}$ & $\begin{array}{r}3 \\
2 \\
10 \\
17 \\
18\end{array}$ & $\begin{array}{r}6 \\
2 \\
21 \\
21 \\
21\end{array}$ \\
\hline $\mathrm{T} 1-22.5 \mathrm{Cb}-10 \mathrm{Al}-0.5 \mathrm{Sn}$ & $\begin{array}{c}\text { PT } \\
1200 \\
1400 \\
1600\end{array}$ & $\begin{array}{r}170,200 \\
134,400 \\
80,700 \\
50,100\end{array}$ & $\begin{array}{r}165,000 \\
125,000 \\
78,000 \\
44,000\end{array}$ & $\begin{array}{l}3 \\
4.5 \\
3 \\
4.5\end{array}$ & $\begin{array}{l}4 \\
7 \\
7.5 \\
6\end{array}$ \\
\hline $\mathrm{TA}-22.5 \mathrm{Cb}-10 \mathrm{Al}-5 \mathrm{Hf}$ & $\begin{array}{c}\mathrm{RT} \\
1200 \\
1400 \\
1600\end{array}$ & $\begin{array}{r}170,500 \\
168,000 \\
98,300 \\
54,600\end{array}$ & $\begin{array}{r}154,000 \\
85,000 \\
48,000\end{array}$ & $\begin{array}{l}-5 \\
8 \\
5\end{array}$ & $\begin{array}{r}5 \\
8 \\
16 \\
5\end{array}$ \\
\hline Ti-22.5Cb-10Al-1Hf & $\begin{array}{c}\text { RT } \\
1200 \\
1400 \\
1600 \\
1800\end{array}$ & $\begin{array}{r}131,500 \\
120,800 \\
140,500 \\
90,000 \\
37,900\end{array}$ & $\begin{array}{r}120,000 \\
105,000 \\
125,000 \\
78,000 \\
33,000\end{array}$ & $\begin{array}{l}9 \\
4 \\
7 \\
4 \\
8\end{array}$ & $\begin{array}{r}8 \\
11 \\
21 \\
8 \\
14\end{array}$ \\
\hline
\end{tabular}


TABLE VI (contInued)

\begin{tabular}{|c|c|c|c|c|c|}
\hline $\begin{array}{c}\text { Alloy Composition } \\
\text { (wt \%) }\end{array}$ & $\begin{array}{l}\text { Test } \\
\text { Temp } \\
\left({ }^{\circ} \mathrm{F}\right)\end{array}$ & $\begin{array}{l}\text { UTS } \\
\text { (psi) }\end{array}$ & $\begin{array}{r}0.2 \% \text { YS } \\
\text { (psi) }\end{array}$ & $\begin{array}{l}\% \text { El. in } \\
0.7 \text { in. }\end{array}$ & $\$ B \cdot R A$ \\
\hline $\mathrm{Ti}-22.5 \mathrm{Cb}-12.5 \mathrm{Al}-2 \mathrm{Zr}$ & $\begin{array}{c}\mathrm{RT} \\
1200 \\
1600 \\
1800\end{array}$ & $\begin{array}{r}148,600 \\
123,000 \\
72,100 \\
25,100\end{array}$ & $\begin{array}{r}133,000 \\
105,000 \\
59,000 \\
19,000\end{array}$ & $\begin{array}{l}1.5 \\
24 \\
21 \\
97\end{array}$ & $\begin{array}{r}6 \\
54 \\
47 \\
>90\end{array}$ \\
\hline $\mathrm{T} 1-22.5 \mathrm{Cb}-12.5 \mathrm{Al}-1 \mathrm{Zr}$ & $\begin{array}{l}-90 \\
\mathrm{RT} \\
400 \\
600(\mathrm{~A}) \\
600(\mathrm{~B}) \\
800 \\
1000(\mathrm{~A}) \\
1000(\mathrm{~B}) \\
1200 \\
1400 \\
1600 \\
1800\end{array}$ & $\begin{array}{r}169,100 \\
131,500 \\
138,200 \\
164,700 \\
166,300 \\
122,600 \\
156,000 \\
160,000 \\
118,600 \\
83,400 \\
59,100 \\
29,900\end{array}$ & $\begin{array}{r}151,000 \\
104,000 \\
123,000 \\
148,000 \\
89,000 \\
138,000 \\
110,000 \\
83,000 \\
63,000 \\
52,000 \\
24,000\end{array}$ & $\begin{array}{l}3 \\
7 \\
3 \\
-- \\
7.5 \\
11 \\
6 \\
4.5 \\
28 \\
24 \\
28 \\
10\end{array}$ & $\begin{array}{r}7 \\
13 \\
8 \\
4 \\
5 \\
15 \\
8 \\
14 \\
38 \\
42 \\
83 \\
>90\end{array}$ \\
\hline Ti-22.5Cb-12.5Al-0.5Zx & $\begin{array}{c}\mathrm{RT} \\
800 \\
1200 \\
1400 \\
1600 \\
1800\end{array}$ & $\begin{array}{r}158,100 \\
160,300 \\
107,500 \\
115,400 \\
106,500 \\
54,900\end{array}$ & $\begin{array}{r}129,000 \\
83,000 \\
101,000 \\
92,000 \\
45,000\end{array}$ & $\begin{array}{r}0 \\
12 \\
28 \\
14 \\
8 \\
7\end{array}$ & $\begin{array}{l}2 \\
21 \\
59 \\
32 \\
11 \\
14\end{array}$ \\
\hline $\mathrm{T} 1-22.5 \mathrm{Cb}-12.5 \mathrm{Al}-0.2 \mathrm{Zr}$ & $\begin{array}{c}\mathrm{RT} \\
800 \\
1200 \\
1400 \\
1600\end{array}$ & $\begin{array}{r}149,300 \\
149,300 \\
113,700 \\
95,800 \\
49,100\end{array}$ & $\begin{array}{r}123,000 \\
100,000 \\
89,000 \\
42,000\end{array}$ & $\begin{array}{r}-7 \\
10 \\
10 \\
9 \\
33\end{array}$ & $\begin{array}{l}-\infty \\
11 \\
22 \\
18 \\
55\end{array}$ \\
\hline $\mathrm{T} 1-22.5 \mathrm{Cb}-12.5 \mathrm{~A} 1-5 \mathrm{Sn}$ & $\begin{array}{c}\mathrm{RT} \\
1200 \\
1400 \\
1600 \\
1800\end{array}$ & $\begin{array}{r}98,800 \\
107,000 \\
102,500 \\
79,800 \\
74,700\end{array}$ & $\begin{array}{l}75,000 \\
84,000 \\
71,000 \\
60,000\end{array}$ & $\begin{array}{r}0 \\
10 \\
7 \\
5 \\
7\end{array}$ & $\begin{array}{l}0 \\
13 \\
14 \\
14 \\
14\end{array}$ \\
\hline$T 1-22.5 \mathrm{Cb}-12.5 \mathrm{~A} 1-1 \mathrm{Sn}$ & $\begin{array}{c}\mathrm{RT} \\
1200 \\
1400 \\
1600\end{array}$ & $\begin{array}{r}156,000 \\
113,700 \\
93,700 \\
63,200\end{array}$ & $\begin{array}{l}95,000 \\
84,000 \\
53,000\end{array}$ & $\begin{array}{l}19 \\
10 \\
16\end{array}$ & $\begin{array}{l}5 \\
34 \\
23 \\
27\end{array}$ \\
\hline
\end{tabular}


TABLE VI (continued)

\begin{tabular}{|c|c|c|c|c|c|}
\hline $\begin{array}{l}\text { Alloy Composition } \\
\text { (wt } \% \text { ) }\end{array}$ & $\begin{array}{l}\text { Test } \\
\text { Temp } \\
\left({ }^{\circ} \mathrm{F}\right)\end{array}$ & $\begin{array}{l}\text { UTS } \\
\text { (psi) }\end{array}$ & $\begin{array}{l}0.2 \% \text { YS } \\
\text { (psI) }\end{array}$ & $\begin{array}{l}\% \text { El. in } \\
0.7 \text { in. }\end{array}$ & $\%$ RA \\
\hline $\mathrm{T} 1-22.5 \mathrm{Cb}-12.5 \mathrm{Al}-0.5 \mathrm{Sn}$ & $\begin{array}{c}\text { RT } \\
1200 \\
1400 \\
1600\end{array}$ & $\begin{array}{r}151,500 \\
118,500 \\
123,200 \\
70,300\end{array}$ & $\begin{array}{r}134,000 \\
101,000 \\
112,000 \\
57,000\end{array}$ & $\begin{array}{r}3 \\
35 \\
3 \\
12\end{array}$ & $\begin{array}{r}6 \\
>95 \\
7 \\
18\end{array}$ \\
\hline $\mathrm{Ti}-22.5 \mathrm{Cb}-12.5 \mathrm{Al}-5 \mathrm{HF}$ & $\begin{array}{c}\text { RT } \\
1200 \\
1400 \\
1600 \\
1800\end{array}$ & $\begin{array}{r}157,600 \\
118,600 \\
90,900 \\
84,300 \\
59,300\end{array}$ & $\begin{array}{r}147,000 \\
74,000 \\
73,000 \\
66,000 \\
49,000\end{array}$ & $\begin{array}{r}6 \\
32 \\
21 \\
32 \\
35\end{array}$ & $\begin{array}{l}8 \\
40 \\
53 \\
64 \\
75\end{array}$ \\
\hline $\mathrm{T1}-22.5 \mathrm{Cb}-12.5 \mathrm{Al}-2.5 \mathrm{Hf}$ & $\begin{array}{l}\text { RT } \\
1200(\mathrm{~A}) \\
1200(\mathrm{~B}) \\
1400 \\
1600\end{array}$ & $\begin{array}{r}156,800 \\
185,000 \\
147,100 \\
70,300 \\
64,200\end{array}$ & $\begin{array}{c}143,000 \\
133,000 \\
61,000 \\
52,000\end{array}$ & $\begin{array}{l}3 \\
-5.5 \\
61 \\
18\end{array}$ & $\begin{array}{l}9.5 \\
3.5 \\
12 \\
74 \\
21\end{array}$ \\
\hline $\mathrm{T} 1-22.5 \mathrm{Cb}-12.5 \mathrm{Al}-1 \mathrm{HP}$ & $\begin{array}{l}-90 \\
R T \\
400(\mathrm{~A}) \\
400(\mathrm{~B}) \\
600 \\
800 \\
1000 \\
1200 \\
1400 \\
1600 \\
1800\end{array}$ & $\begin{array}{r}135,100 \\
153,700 \\
152,200 \\
126,400 \\
147,100 \\
140,500 \\
166,900 \\
112,000 \\
85,600 \\
82,500 \\
48,900\end{array}$ & $\begin{array}{r}119,000 \\
140,000 \\
95,000 \\
131,000 \\
114,000 \\
158,000 \\
79,000 \\
65,000 \\
55,000 \\
41,000\end{array}$ & $\begin{array}{c}3 \\
6 \\
-\infty \\
11 \\
3 \\
13 \\
1.5 \\
15 \\
28 \\
30 \\
20\end{array}$ & $\begin{array}{l}7.5 \\
7 \\
2 \\
15 \\
12 \\
23 \\
2 \\
30 \\
57 \\
75 \\
45\end{array}$ \\
\hline $\mathrm{T} 1-22.5 \mathrm{Cb}-15 \mathrm{Al}-1.5 \mathrm{Zr}$ & $\begin{array}{c}\mathrm{RT} \\
1200 \\
1600 \\
1800\end{array}$ & $\begin{array}{r}148,600 \\
133,100 \\
94,000 \\
48,300\end{array}$ & $\begin{array}{r}146,000 \\
106,000 \\
83,000 \\
38,000\end{array}$ & $\begin{array}{l}1.5 \\
11 \\
13 \\
45\end{array}$ & $\begin{array}{l}4 \\
17 \\
17 \\
60\end{array}$ \\
\hline$T H-22.5 \mathrm{Cb}-15 \mathrm{~A} 1-1 \mathrm{Zr}$ & $\begin{array}{l}\text { RT } \\
1200 \\
1400 \\
1600\end{array}$ & $\begin{array}{r}144,900 \\
151,600 \\
138,200 \\
96,600\end{array}$ & $\begin{array}{r}113,000 \\
109,000 \\
72,000\end{array}$ & $\begin{array}{l}0 \\
14 \\
20 \\
11\end{array}$ & $\begin{array}{r}1 \\
20 \\
50 \\
21\end{array}$ \\
\hline
\end{tabular}


TABLE VI (continued)

\begin{tabular}{|c|c|c|c|c|c|}
\hline $\begin{array}{l}\text { Alloy Composition } \\
\text { (wt \%) }\end{array}$ & $\begin{array}{l}\text { Test } \\
\text { Temp } \\
\left({ }^{\circ} \mathrm{F}\right)\end{array}$ & $\begin{array}{l}\text { UTS } \\
\text { (psi) }\end{array}$ & $\begin{array}{r}0.2 \% \text { YS } \\
\text { (psi) }\end{array}$ & $\begin{array}{l}\text { \% El. in } \\
0.7 \text { in. }\end{array}$ & $\% \mathrm{RA}$ \\
\hline $\mathrm{T} 1-22.5 \mathrm{Cb}-15 \mathrm{Al}-0.5 \mathrm{Zr}$ & $\begin{array}{c}\text { RT } \\
1200 \\
1400 \\
1600 \\
1800\end{array}$ & $\begin{array}{r}120,800 \\
144,900 \\
122,600 \\
100,300 \\
88,900\end{array}$ & $\begin{array}{r}109,200 \\
98,000 \\
98,000 \\
79,000\end{array}$ & $\begin{array}{r}0 \\
10 \\
7 \\
3 \\
7\end{array}$ & $\begin{array}{r}2 \\
15 \\
11 \\
17 \\
8\end{array}$ \\
\hline$T 1-22.5 \mathrm{Cb}-15 \mathrm{Al}-0.22 \mathrm{r}$ & $\begin{array}{c}\text { RT } \\
1200 \\
1400 \\
1600\end{array}$ & $\begin{array}{r}153,700 \\
129,300 \\
128,600 \\
91,100\end{array}$ & $\begin{array}{r}100,000 \\
108,000 \\
74,000\end{array}$ & $\begin{array}{l}-5 \\
70 \\
12\end{array}$ & $\begin{array}{c}1.5 \\
13 \\
9 \\
16\end{array}$ \\
\hline $\mathrm{Ti}-22.5 \mathrm{Cb}-15 \mathrm{Al}-5 \mathrm{Sn}$ & $\begin{array}{c}\text { RT } \\
1200 \\
1400 \\
1600 \\
1800\end{array}$ & $\begin{array}{r}173,500 \\
159,400 \\
163,900 \\
109,300 \\
47,800\end{array}$ & $\begin{array}{c}160,000 \\
135,000 \\
96,000 \\
37,000\end{array}$ & $\begin{array}{l}1.5 \\
9.5 \\
1.5 \\
6 \\
38\end{array}$ & $\begin{array}{r}6 \\
41 \\
5 \\
12 \\
32\end{array}$ \\
\hline$T 1-22.5 \mathrm{Cb}-15 \mathrm{Al}-1 \mathrm{Sn}$ & $\begin{array}{c}R T \\
1200 \\
1400 \\
1600 \\
1800\end{array}$ & $\begin{array}{r}125,200 \\
123,000 \\
83,400 \\
88,900 \\
91,100\end{array}$ & $\begin{array}{r}123,000 \\
101,000 \\
65,000 \\
70,000 \\
81,000\end{array}$ & $\begin{array}{l}1 \\
5 \\
7 \\
5 \\
7\end{array}$ & $\begin{array}{r}3 \\
6 \\
20 \\
5 \\
11\end{array}$ \\
\hline $\mathrm{Ti}-22.5 \mathrm{Cb}-15 \mathrm{Al}-0.5 \mathrm{Sn}$ & $\begin{array}{c}\text { RT } \\
1200 \\
1600\end{array}$ & $\begin{array}{r}137,500 \\
126,800 \\
88,700\end{array}$ & $\begin{array}{c}102,000 \\
73,000\end{array}$ & $\begin{array}{l}10 \\
7.5\end{array}$ & $\begin{array}{l}1.5 \\
16 \\
15\end{array}$ \\
\hline $\mathrm{Ti}-22.5 \mathrm{Cb}-15 \mathrm{Al}-5 \mathrm{HP}$ & $\begin{array}{l}\text { RT } \\
1200 \\
.1600 \\
1800\end{array}$ & $\begin{array}{r}175,700 \\
166,600 \\
90,700 \\
42,600\end{array}$ & $\begin{array}{r}149,000 \\
78,000 \\
35,000\end{array}$ & $\begin{array}{l}-4.5 \\
23 \\
99\end{array}$ & $\begin{array}{r}2 \\
18 \\
46 \\
>90\end{array}$ \\
\hline $\begin{array}{l}\text { Ti-22.5Cb-7.5Al-0.75 si } \\
\text { (Treated } 16 \mathrm{hr}-1200^{\circ} \mathrm{F}-\mathrm{AC} \text { ) }\end{array}$ & $\mathrm{RT}$ & 177,400 & -- & 1.5 & 4 \\
\hline
\end{tabular}


TABLE VI (continued)

\begin{tabular}{|c|c|c|c|c|c|}
\hline $\begin{array}{c}\text { Alloy Composition } \\
\text { (wt } \not) \text { ) }\end{array}$ & $\begin{array}{l}\text { Test } \\
\text { Temp } \\
\left({ }^{\circ} \mathrm{F}\right)\end{array}$ & $\begin{array}{l}\text { UTS } \\
\text { (psi) }\end{array}$ & $\begin{array}{r}0.2 \% \text { YS } \\
\text { (psi) }\end{array}$ & $\begin{array}{l}\% \text { El. in } \\
0.7 \text { in }\end{array}$ & \% RA \\
\hline $\begin{array}{l}\text { T1-22.5Cb-12.5Al-12r } \\
\text { (Treated } 16 \mathrm{hr}-1200^{\circ} \mathrm{F}-\mathrm{AC} \text { ) }\end{array}$ & $\begin{array}{r}600 \\
800 \\
1000\end{array}$ & $\begin{array}{l}166,900 \\
140,700 \\
173,300\end{array}$ & $\begin{array}{l}155,000 \\
119,000 \\
168,000\end{array}$ & $\begin{array}{c}4 \\
11\end{array}$ & $\begin{array}{r}6 \\
27 \\
4\end{array}$ \\
\hline $\begin{array}{l}\text { Ti-22.5Cb-12.5Al-1Hf } \\
\text { (Treated } 16 \mathrm{hr}-1600^{\circ} \mathrm{F}-\mathrm{AC} \text { ) }\end{array}$ & $\begin{array}{l}\mathrm{RT} \\
400 \\
1000\end{array}$ & $\begin{array}{l}116,600 \\
131,500 \\
120,100\end{array}$ & $\begin{array}{r}101,000 \\
95,000 \\
80,000\end{array}$ & $\begin{array}{l}3 \\
8.5 \\
31\end{array}$ & $\begin{array}{r}8 \\
13 \\
44\end{array}$ \\
\hline
\end{tabular}

* Broke at shoulder. 
TABLE VII

GUIDED BEND TEST DATA FOR TITANIUM ALLOY SHEET APPROXIMATELY 1/16-INCH THICKNESS

\begin{tabular}{|c|c|c|c|c|c|}
\hline $\begin{array}{l}\text { Alloy Composition } \\
\text { (Nominal wt } \% \text { ) }\end{array}$ & $\begin{array}{l}\text { Rolling } \\
\text { Temp. } \\
\left({ }^{\circ} \mathrm{F}\right)\end{array}$ & $\begin{array}{l}\text { Heat } \\
\text { Treatment }\end{array}$ & $\begin{array}{l}\text { Pass. } \\
\left(R_{t}\right)\end{array}$ & $\begin{array}{l}\text { Fail } \\
\left(R_{t}\right)\end{array}$ & $\begin{array}{c}\text { Pailure } \\
\text { Angle } \\
\text { (deg) }\end{array}$ \\
\hline Ti-15Cb-10A1 & $\begin{array}{l}1650 \\
1600 \\
1600 \\
1700 \\
1700 \\
1600 \\
1600 \\
1650 \\
1700 \\
1600\end{array}$ & $\begin{array}{l}6 \mathrm{hr}-1500^{\circ} \mathrm{F}-\mathrm{AC} \\
80 \mathrm{~min}-1600^{\circ} \mathrm{F}-\mathrm{AC} \\
3 \mathrm{hr}-1600^{\circ} \mathrm{F}-\mathrm{AC} \\
80 \mathrm{~min}-1600^{\circ} \mathrm{F}-\mathrm{AC} \\
80 \mathrm{~min}-1600^{\circ} \mathrm{F}-\mathrm{AC} \\
80 \mathrm{~min}-1650^{\circ} \mathrm{F}-\mathrm{AC} \\
30 \mathrm{~min}-1750^{\circ} \mathrm{F}-\mathrm{AC} \\
\text { none } \\
80 \mathrm{~min}-1650^{\circ} \mathrm{F}-\mathrm{AC} \\
3 \mathrm{hr}-1600^{\circ} \mathrm{F}-\mathrm{AC} \\
+16 \mathrm{hr}-1450^{\circ} \mathrm{F}-\mathrm{AC}\end{array}$ & $\begin{array}{c}9 \\
4 \\
11 \\
3 \\
2.5 \\
6 \\
6 \\
16 \\
8\end{array}$ & $\begin{array}{l}5.5 \\
3 \\
8 \\
2 \\
4 \\
10 \\
5.5 \\
16\end{array}$ & 110 \\
\hline $\mathrm{TI}-17.5 \mathrm{Cb}-15 \mathrm{Al}$ & $\begin{array}{l}2050-1950 \\
2050-1950 \\
2000-2050 \\
2050-2000 \\
2050-1950 \\
2050-1950 \\
2050-1950 \\
2050-1950 \\
2050-1950 \\
2050-1950 \\
2050-1950 \\
2000-2050 \\
2050-1950 \\
2050-2000\end{array}$ & $\begin{array}{c}\text { none } \\
\text { none } \\
\text { none } \\
\text { none } \\
6 \mathrm{hr}-1500^{\circ} \mathrm{F}-\mathrm{AC} \\
24 \mathrm{hr}-1500^{\circ} \mathrm{F}-\mathrm{AC} \\
90 \mathrm{~min}-1600^{\circ} \mathrm{F}-\mathrm{AC} \\
2 \mathrm{hr}-1650^{\circ} \mathrm{F}-\mathrm{AC} \\
90 \mathrm{~min}-1750^{\circ} \mathrm{F}-\mathrm{AC} \\
90 \mathrm{~min}-1750^{\circ} \mathrm{F}-\mathrm{AC} \\
90 \mathrm{~min}-1750^{\circ} \mathrm{F}-\mathrm{AC} \\
90 \mathrm{~min}-1700^{\circ} \mathrm{F}-\mathrm{AC} \\
90 \mathrm{~min}-1700^{\circ} \mathrm{F}-\mathrm{AC} \\
90 \mathrm{~min}-1700^{\circ} \mathrm{F}-\mathrm{AC}\end{array}$ & $\begin{array}{r}14 \\
14 \\
12 \\
15 \\
4 \\
14 \\
6 \\
13 \\
16 \\
24 \\
15 \\
20\end{array}$ & $\begin{array}{c}9 \\
9 \\
20 \\
10 \\
9 \\
14 \\
3 \\
9 \\
4 \\
10.5 \\
10 \\
16 \\
9.5 \\
12\end{array}$ & $\begin{array}{r}120 \\
180 \\
130 \\
60 \\
20 \\
20 \\
45 \\
90\end{array}$ \\
\hline
\end{tabular}




\section{TABLE VIII}

ROOM-TEMPERATURE TENSIIE RESULTS FOR SHEET T1-15Cb-10AI

WITH SEVERAL HEAT TRGATMENTS AND STRESS-THERMAL EXPOSURES

\begin{tabular}{|c|c|c|c|c|c|c|c|c|}
\hline $\begin{array}{l}\text { Rolling } \\
\text { Temp } \\
\left({ }^{\circ} \mathrm{F}\right)\end{array}$ & Prior Treatinent & $\frac{\text { Yield }}{0.01 \%}$ & $\frac{\text { Strength }}{0.18}$ & $\frac{(p 81)}{0.2 \%}$ & $\begin{array}{l}\text { OTS } \\
\text { (p81) }\end{array}$ & p81 ${ }^{E} \times 10^{-6}$ & $\begin{array}{l}\text { Elon } \\
\% \text { in } 1\end{array}$ & in. \\
\hline 1600 & none & 101,000 & 154,000 & 165,000 & $>172,000$ & 15.9 & & * \\
\hline 1600 & none & 103,000 & $161, \infty 00$ & 165,000 & 175,000 & 13.7 & 3.3 & \\
\hline 1650 & none & 93,800 & 129,000 & 142,000 & 174,000 & 24.6 & 3.5 & $* *$ \\
\hline 1650 & none & 122,000 & $148, \infty 00$ & 159,000 & 177,000 & 15.3 & 5 & \\
\hline 2600 & $6 h-1500^{\circ} F-A C$ & 54,700 & 78,000 & 89,600 & 100,000 & 13.1 & 1.3 & \\
\hline 1600 & $6 h-1500^{\circ} \mathrm{F}-\mathrm{AC}$ & 71,000 & 82,800 & 84,500 & 129,000 & 12.0 & 3.3 & $* *$ \\
\hline 1600 & $\begin{array}{l}6 h-1500^{\circ} \mathrm{F}-\mathrm{AC}+ \\
45 \mathrm{~h}-1400^{\circ} \mathrm{F}-5,000 \text { psi }\end{array}$ & 83,400 & $-\infty-\infty$ & $-\infty-\infty$ & 117,000 & 1409 & 1.5 & \\
\hline 2600 & $\begin{array}{l}6 h-1500^{\circ} \mathrm{F}-\mathrm{AC}+ \\
3 \mathrm{~h}-1500^{\circ} \mathrm{F}-5,000 \text { ps1 }\end{array}$ & 67,000 & 89,000 & 94,000 & 108,000 & 11.8 & & $* *$ \\
\hline 1650 & $6 h-1500^{\circ} \mathrm{P}-\mathrm{AC}$ & 75,500 & 97,000 & 102,000 & 120,000 & 11.6 & 2 & $\#$ \\
\hline 1650 & $6 h-1500^{\circ} \mathrm{F}-\mathrm{AC}$ & $41,900 ?$ & 80,500 & 86,500 & 99,100 & 15.3 & $e$ & \\
\hline 1650 & $\begin{array}{l}6 h-1500^{\circ} F-A C+ \\
1500^{\circ} F-5,000 \text { psi to } \\
20 \% \text { creep }\end{array}$ & - & מ-חמ-ח- & $\infty-\infty-\infty$ & 113,000 & 13.6 & 2 & \\
\hline 1600 & $80 \mathrm{~m}-160^{\circ} \mathrm{F}-\mathrm{AC}$ & 86,400 & 107,700 & 113,600 & $>125,000 *$ & 13.5 & & * \\
\hline 1650 & $80 m-1600^{\circ} \mathrm{F}-\mathrm{AC}$ & 84,500 & 109,000 & 117,000 & * & 13.1 & & * \\
\hline 1650 & $80 m-1600^{\circ} \mathrm{F}-\mathrm{AC}$ & 115,000 & 127,000 & 130,000 & $>130,000 *$ & 13.8 & 2 & $*$ \\
\hline 2600 & $80 \mathrm{~m}-1650^{\circ} \mathrm{F}-\mathrm{AC}$ & 93,200 & 116,000 & 124,000 & $>127,000 *$ & 13.4 & & * \\
\hline 1600 & $\begin{array}{l}80 \mathrm{~m}-1650^{\circ} \mathrm{F}-\mathrm{AC}+ \\
167 \mathrm{hr}-1200^{\circ} \mathrm{F}-5,000 \mathrm{ps} 1\end{array}$ & 48,800 & - - - & $\infty-\infty+\infty$ & $-\infty+\infty$ & 19.8 & & * \\
\hline
\end{tabular}

* Broke through pin hole. 
TABLE :IX

ROOM-TEMPERATURE TENSIIE RESULTS FOR SHEET Ti-17.5Cb-15A]

WITH SEVERAL HEAT TREATMENTS AND STRESS-THERMAL EXPOSURES

\begin{tabular}{|c|c|c|c|c|c|c|c|}
\hline $\begin{array}{l}\text { Rolling } \\
\text { Temp } \\
\left({ }^{\circ} \mathrm{F}\right)\end{array}$ & Prior Treatnent & $\frac{\text { Yield }}{0.01 \%}$ & $\frac{\text { Strength }}{0.1 \%}$ & $\frac{(p s 1)}{0.2 \%}$ & $\begin{array}{l}\text { UTS } \\
\text { (psi) }\end{array}$ & $\mathrm{psi}^{\mathrm{E}} \times 10^{-6}$ & $\begin{array}{l}\text { Elong. } \\
\% \text { in } 1 \text { in. }\end{array}$ \\
\hline $2050-1950$ & none & 82,600 & 100,000 & 107,300 & 133,600 & 12.5 & 3.5 \\
\hline $2050-1950$ & $6 \mathrm{~h}-1500^{\circ} \mathrm{F}-\mathrm{AL}$ & 56,600 & 76,700 & 79,300 & 98,200 & 11.0 & 3.5 \\
\hline $2050-1950$ & $6 \mathrm{~h}-1500^{\circ} \mathrm{F}-\mathrm{AC}$ & 66,500 & 68,600 & 69,500 & 94,600 & 11.5 & 5 \\
\hline $2050-1950$ & $\begin{array}{l}6 \mathrm{~h}-1500^{\circ} \mathrm{F}-\mathrm{AC}+ \\
167 \mathrm{~h}-1500^{\circ} \mathrm{F}-7,500 \text { psi }\end{array}$ & 4,700 & 47,600 & 47,900 & 67,800 & 11.9 & 405 \\
\hline $2050-2950$ & $\begin{array}{l}6 \mathrm{~h}-1500^{\circ} \mathrm{F}-\mathrm{AC}+ \\
170 \mathrm{~h}-2500^{\circ} \mathrm{F}-1 \mathrm{C}, 000 \mathrm{ps} 1\end{array}$ & 40,800 & 49,600 & 50,500 & 75,000 & 1404 & 40.5 \\
\hline $2050-1950$ & $90 \mathrm{~m}-1600^{\circ} \mathrm{F}-\mathrm{ACC}$ & 63,500 & 77,500 & 84,000 & 109,000 & 13.5 & $3.5 *$ \\
\hline $2050-1950$ & $\begin{array}{l}90 \mathrm{~m}-3600 \cdot \mathrm{F}-\mathrm{s} C \mathrm{C}+ \\
167 \mathrm{~h}-1500^{\circ} \mathrm{F}-5,000 \mathrm{ps} 1\end{array}$ & 49,100 & 50,600 & 50,800 & 66,900 & 11.6 & 3.3 \\
\hline $2050-1950$ & $90 \mathrm{~m}-1750^{\circ} \mathrm{F}-\mathrm{AC}$ & 60,800 & 65,700 & 65,700 & 65,700 & 15.6 & $<1$ \\
\hline $2050-2950$ & $90 \mathrm{~m}-1750^{\circ} \mathrm{F}-\mathrm{ACC}$ & 56,500 & 61,900 & 62,000 & 63,000 & 13.] & $<1$ \\
\hline $2050-1950$ & none & 91,400 & -..... & $-\infty=-\infty$ & 112,000 & 17.1 & 0 \\
\hline $2050-1550$ & none & 76,700 & $m-\infty$ & manas- & 104,000 & 17.4! & $0 \quad * *$ \\
\hline $2050-1950$ & none & 70,000 & 107,500 & 117,000 & 148,000 & 15.6 & 2.5 \\
\hline $2050-2000$ & none & 92,000 & 108,000 & 114,000 & 139,000 & 12.0 & 3.5 \\
\hline $2050-2000$ & none & 86,000 & 105,000 & -an- & 240,000 & 12.9 & 305 \\
\hline $2050-2000$ & $24 h-1400^{\circ} \mathrm{F}-\mathrm{AC}$ & 74,700 & 77,000 & 77,600 & 102,000 & 12.6 & 505 \\
\hline $2050-2000$ & $24 h-1400^{\circ} F-A C$ & 71,000 & 74,000 & 75,000 & 84,000 & 12.3 & * \\
\hline $2050-1950$ & none & 80,000 & "x-m & " & 151,000 & 1408 & 2 \\
\hline $2000-2050$ & none & - & - & - & 94,000 & 15.2 & 1 \\
\hline
\end{tabular}

* Broke at shoulder. 
TABLE $X$

TENSTII PROPERTIES OE Ti-22.5Cb-10Al

AND TWO IODIFICATIONS

\begin{tabular}{|c|c|c|c|c|c|}
\hline $\begin{array}{c}\text { Alloy Composition } \\
\text { (wt } \text { \& }^{2}\end{array}$ & $\begin{array}{l}\text { Test } \\
\text { Temp } \\
\left({ }^{\circ} \mathrm{F}\right)\end{array}$ & $\begin{array}{l}\text { UTS } \\
(n \leq i)\end{array}$ & $\begin{array}{c}\text { - YS, psi } \\
0.2 \% \\
\text { offset }\end{array}$ & \% El & \% RA \\
\hline $\begin{array}{l}\mathrm{Ti}-22.5 \mathrm{Cb}-10 \mathrm{Al} \mathrm{I}^{*} \\
\mathrm{~T} \mathrm{i}-22.5 \mathrm{Cb}-10 \mathrm{Al}-0.5 \mathrm{Zr} \\
\mathrm{Ti}-22.5 \mathrm{Cb}-10 \mathrm{Al}-2 \mathrm{Hf}\end{array}$ & $\begin{array}{l}\mathrm{RT} \\
\mathrm{RT} \\
\mathrm{RT}\end{array}$ & $\begin{array}{l}169,000 \\
119,300 \\
131,500\end{array}$ & $\begin{array}{l}147,000 \\
120,000\end{array}$ & $\begin{array}{l}0 \\
3 \\
9\end{array}$ & $\begin{array}{l}0 \\
5 \\
8\end{array}$ \\
\hline $\begin{array}{l}\text { Ti-22.5Cb-10Al } \\
\text { Ti-22.5Cb-10AI-0.57r } \\
\text { Ti-22.5Cb-10Al-1Hf }\end{array}$ & $\begin{array}{l}1200 \\
1200 \\
1200\end{array}$ & $\begin{array}{l}147,000 \\
136,000 \\
120,800\end{array}$ & $\begin{array}{l}134,000 \\
113,000 \\
105,000\end{array}$ & $\begin{array}{l}6 \\
8 \\
4\end{array}$ & $\begin{array}{l}12 \\
30 \\
11\end{array}$ \\
\hline $\begin{array}{l}\text { Tj. }-22.5 \mathrm{Cb}-10 \mathrm{Al} \\
\mathrm{Ti}-22.5 \mathrm{Cb}-10 \mathrm{Al}-0.5 \mathrm{Zr} \\
\mathrm{T} 1-22.5 \mathrm{Cb}-10 \mathrm{Al}-1 \mathrm{Hf}\end{array}$ & $\begin{array}{l}u_{100} \\
u_{100} \\
1400\end{array}$ & $\begin{array}{r}84,000 \\
14,100 \\
140,500\end{array}$ & $\begin{array}{r}71,000 \\
123,000 \\
125,000\end{array}$ & $\begin{array}{r}8 \\
10 \\
7\end{array}$ & $\begin{array}{l}11 \\
27 \\
21\end{array}$ \\
\hline $\begin{array}{l}\text { Ti-22.5Cb-10Al } \\
\text { Ti-22.5Cb-10Al-0.5Zr } \\
\text { Ti-22.5Cb-10Al-1Hf }\end{array}$ & $\begin{array}{l}1600 \\
1600 \\
1600\end{array}$ & $\begin{array}{l}43,000 \\
90,600 \\
90,000\end{array}$ & $\begin{array}{l}38,000 \\
76,000 \\
78,000\end{array}$ & $\begin{array}{r}217 \\
10 \\
4\end{array}$ & $\begin{array}{r}-34 \\
18 \\
-8\end{array}$ \\
\hline
\end{tabular}

* Data for the ternary alloy are from previous work, using the same experimental procedures. 
TABLE XI

TENSILE PROPERTIES OF Ti-22.5Cb-12.5Al

AND TWO MODIFICA'PIONS

\begin{tabular}{|c|c|c|c|c|c|}
\hline $\begin{array}{c}\text { Alloy Composition } \\
\text { (ut } y \text { ) }\end{array}$ & $\begin{array}{l}\text { Test } \\
\text { Temp } \\
\left({ }^{\circ} \mathrm{F}\right)\end{array}$ & $\begin{array}{l}\text { UT'S } \\
\text { (psi) }\end{array}$ & $\begin{array}{l}\text { YS, psi } \\
0.2 \% \\
\text { offset }\end{array}$ & 品 $\mathrm{El}$ & $\because \mathrm{RA}$ \\
\hline $\begin{array}{l}\mathrm{Ti}-22 \cdot 5 \mathrm{Cb}-12 \cdot 5 \mathrm{Al}{ }^{*} \\
\mathrm{Ti}-22 \cdot 5 \mathrm{Cb}-12.5 \mathrm{Al}-1 \mathrm{Hf} \\
\mathrm{Ti}-22.5 \mathrm{Cb}-12.5 \mathrm{Al}-1 \mathrm{x}\end{array}$ & $\begin{array}{l}\mathrm{RT} \\
\mathrm{RT} \\
\mathrm{RT}\end{array}$ & $\begin{array}{l}160,000 \\
153,700 \\
131,500\end{array}$ & $\begin{array}{l}140,000 \\
104,000\end{array}$ & $\begin{array}{l}0 \\
6 \\
7\end{array}$ & $\begin{array}{r}0 \\
7 \\
13\end{array}$ \\
\hline $\begin{array}{l}\mathrm{Ti}-22.5 \mathrm{Cb}-12.5 \mathrm{Al} \\
\mathrm{Ti}-22.5 \mathrm{Cb}-12.5 \mathrm{Al}-1 \mathrm{Hf} \\
\mathrm{Ti}-22.5 \mathrm{Cb}-12.5 \mathrm{Al}-1 \mathrm{Zr}\end{array}$ & $\begin{array}{l}1200 \\
1200 \\
1200\end{array}$ & $\begin{array}{l}131,000 \\
132,000 \\
118,600\end{array}$ & $\begin{array}{r}116,000 \\
79,000 \\
83,000\end{array}$ & $\begin{array}{l}17 \\
15 \\
28\end{array}$ & $\begin{array}{l}50 \\
30 \\
38\end{array}$ \\
\hline $\begin{array}{l}\text { Ti-22.5Cb-12.5Al } \\
\text { Ti-22.5Cb-12.5Al-1Hf } \\
\text { Ti-22.5Cb-12.5Al- } 12 \mathrm{rr}\end{array}$ & $\begin{array}{l}1400 \\
1100 \\
1400\end{array}$ & $\begin{array}{l}71,000 \\
85,600 \\
83,400\end{array}$ & $\begin{array}{l}64,000 \\
65,000 \\
63,000\end{array}$ & $\begin{array}{r}3 \\
28 \\
24\end{array}$ & $\begin{array}{r}6 \\
57 \\
42\end{array}$ \\
\hline $\begin{array}{l}\mathrm{Ti}-22.5 \mathrm{Cb}-12.5 \mathrm{Al} \\
\mathrm{Ti}-22.5 \mathrm{Cb}-12.5 \mathrm{Al}-1 \mathrm{Hf} \\
\mathrm{T} \mathrm{i}-22.5 \mathrm{Cb}-12.5 \mathrm{Al}-1 \mathrm{Zr}\end{array}$ & $\begin{array}{l}1600 \\
1600 \\
1600\end{array}$ & $\begin{array}{l}58,000 \\
82,500 \\
59,100\end{array}$ & $\begin{array}{l}47,000 \\
55,000 \\
52,000\end{array}$ & $\begin{array}{r}8 \\
30 \\
28\end{array}$ & $\begin{array}{l}13 \\
75 \\
83\end{array}$ \\
\hline
\end{tabular}

* Data for the ternary alloy are from previous work, using the same experimental procedures. 


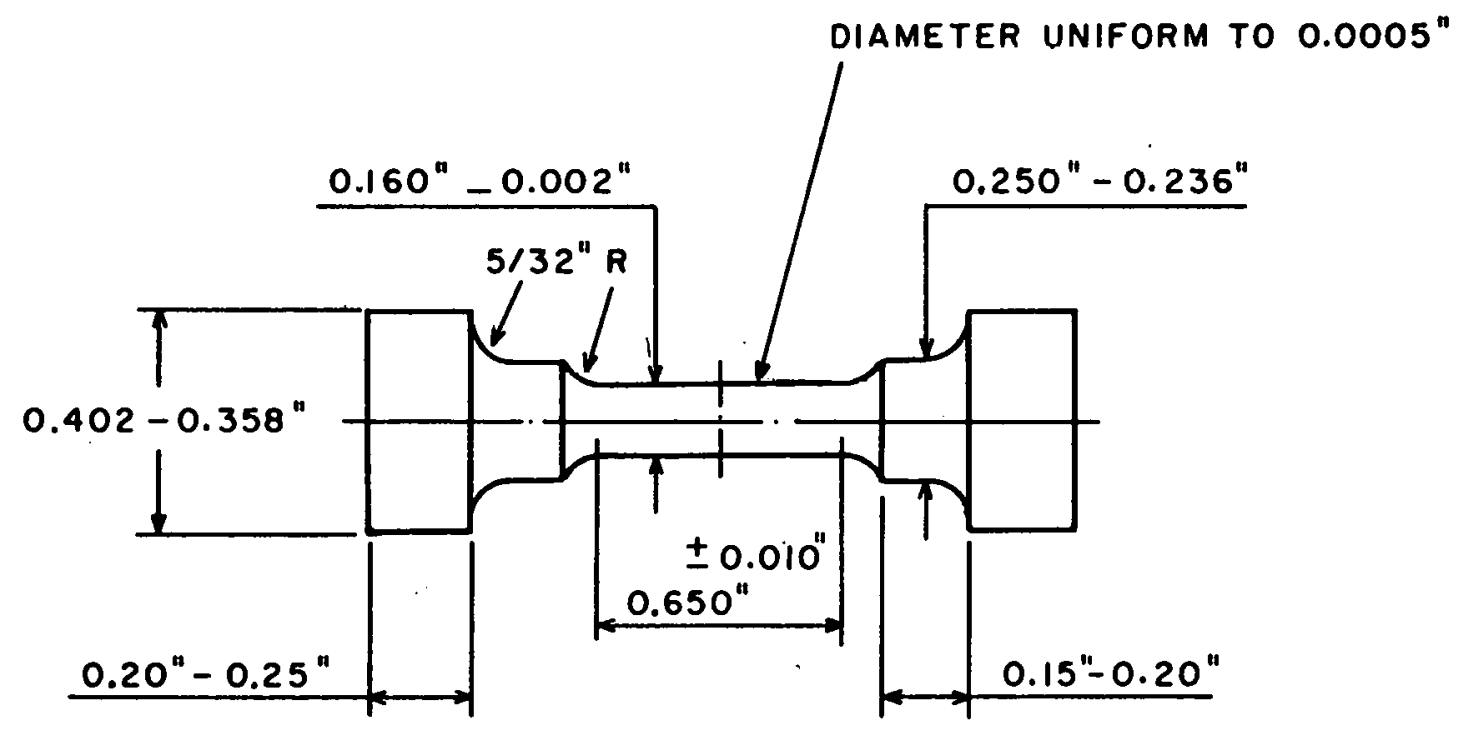

FIG. I HOUNSFIELD TENSILE TEST PIECE. 


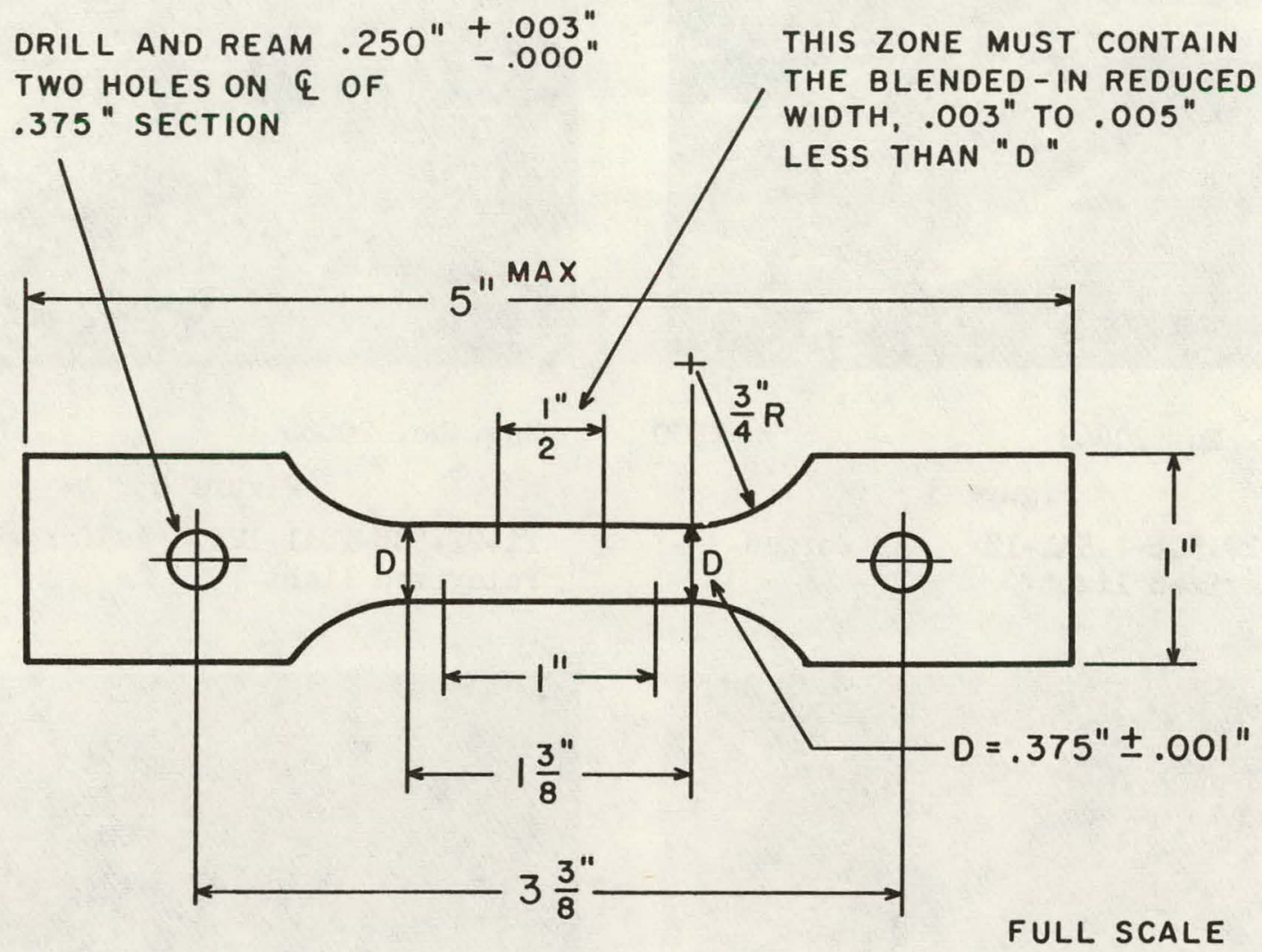

FIG. 2 SPECIFICATIONS FOR I-INCH GAGE LENGTH SHEET TENSILE SPECIMEN. 


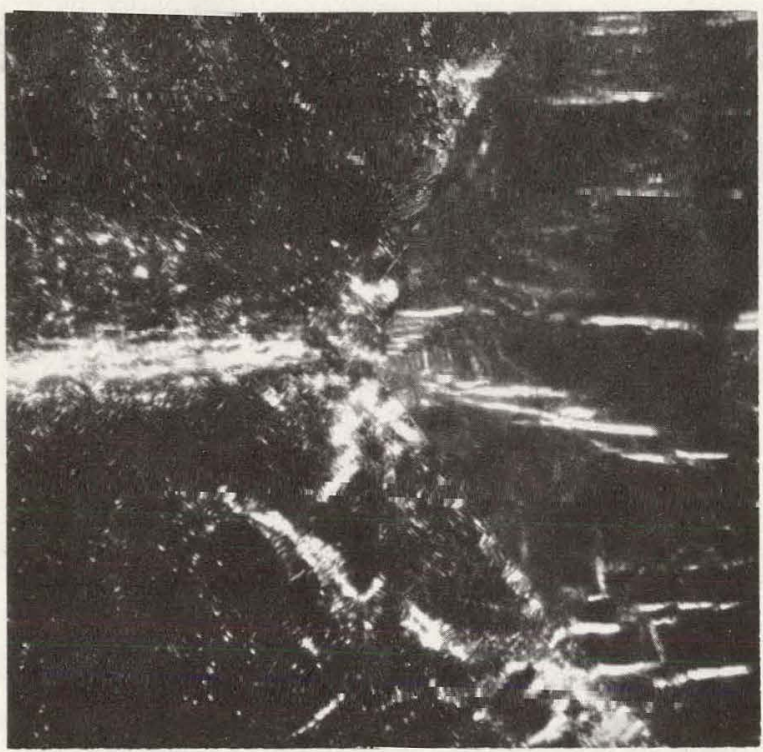

Neg. No. 20663

$\times 500$

Figure 3

Ti-22.5Cb-7.5Al-1Zr. As forged. Polarized light.

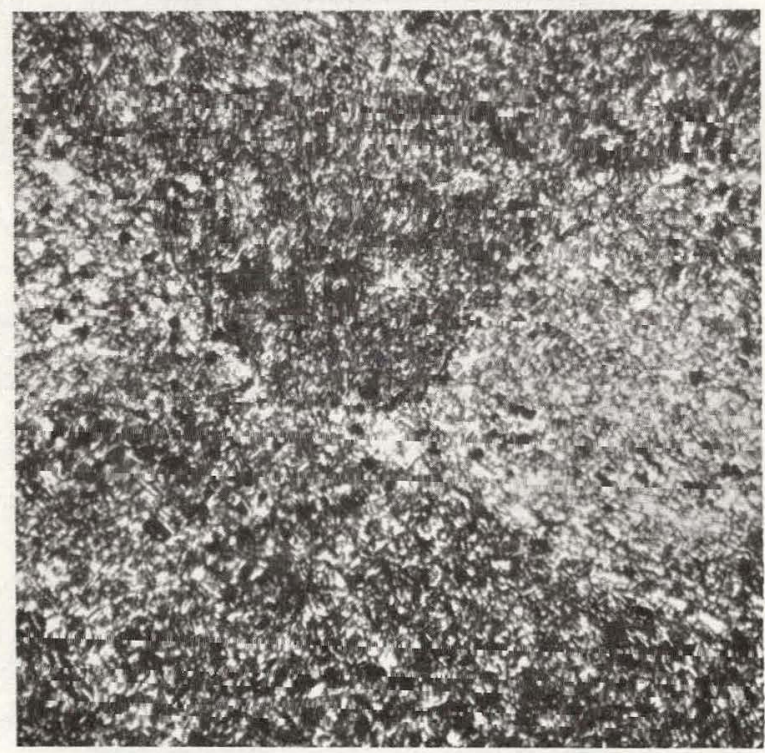

Neg. No. 20674

$\times 500$

Figure 5

Ti-22.5Cb-12.5Al-1Zr. As forged. Polarized light.

Itchant: $\mathrm{HNO}_{3}, \mathrm{HF}, \mathrm{H}_{2} \mathrm{O}_{2}$, glycerine

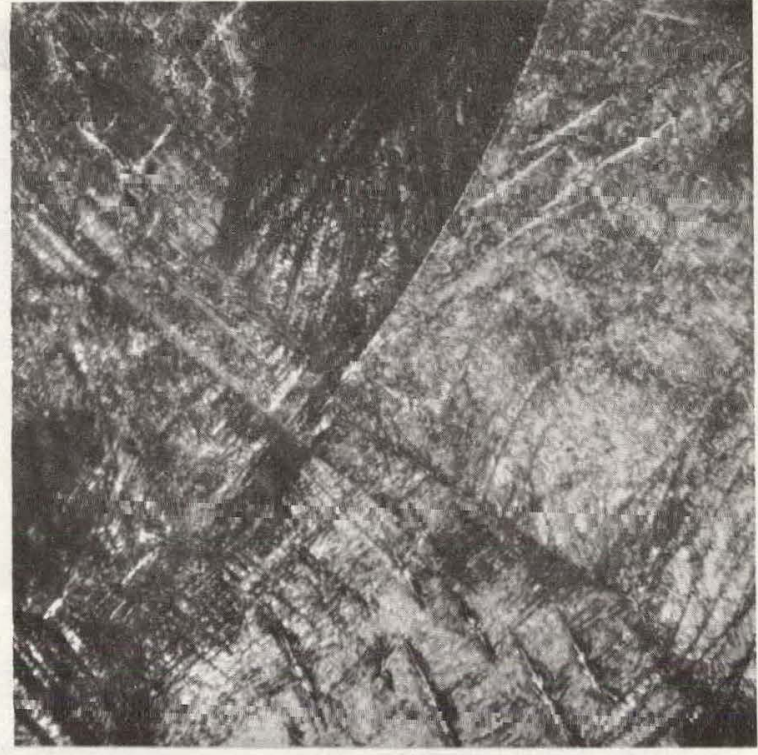

Neg. No. 20666

$\times 500$

Figure 4

T1-22.5Cb-10Al-1Zr. As forged. Polarized light.

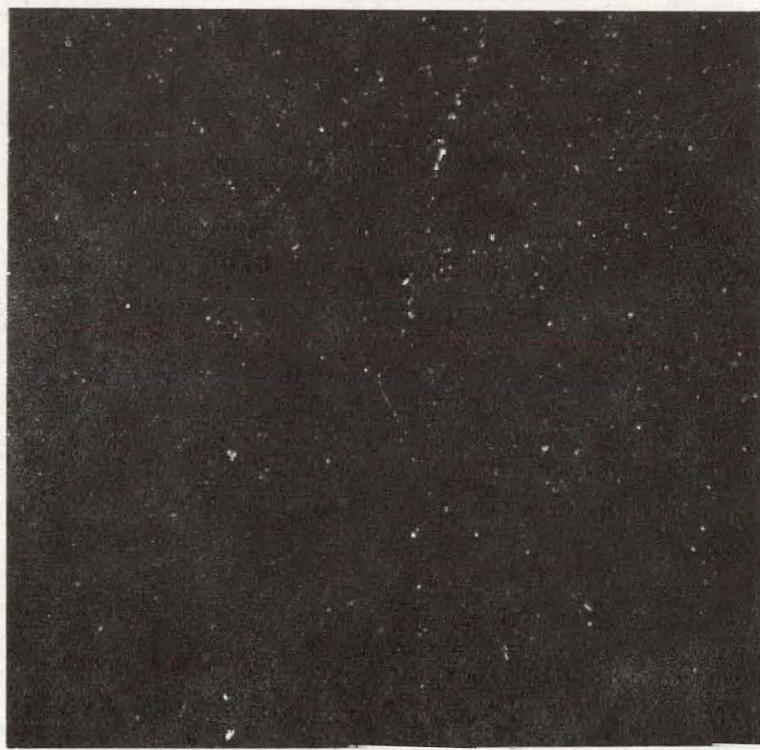

Neg. No. 20676

$\mathbf{X 5 0 0}$

Figure 6

Ti-22.5Cb-15Al-1Zr. As forged. Polarized light. 


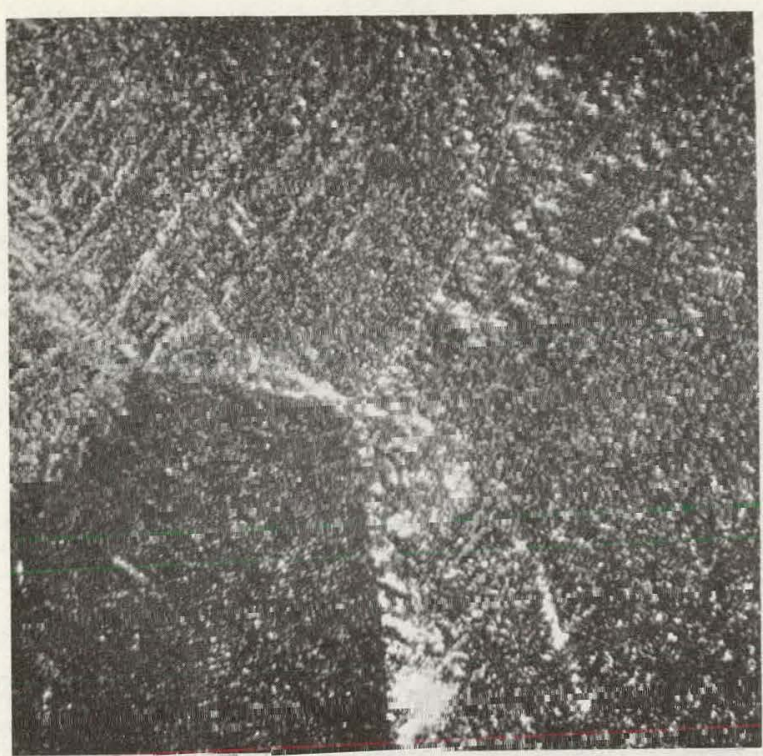

Neg. No. 20667

$\mathbf{X 5 0 0}$

Figure 7

Ti-22.5Cb-10Al-0.5Zr. As forged. Polarized light.

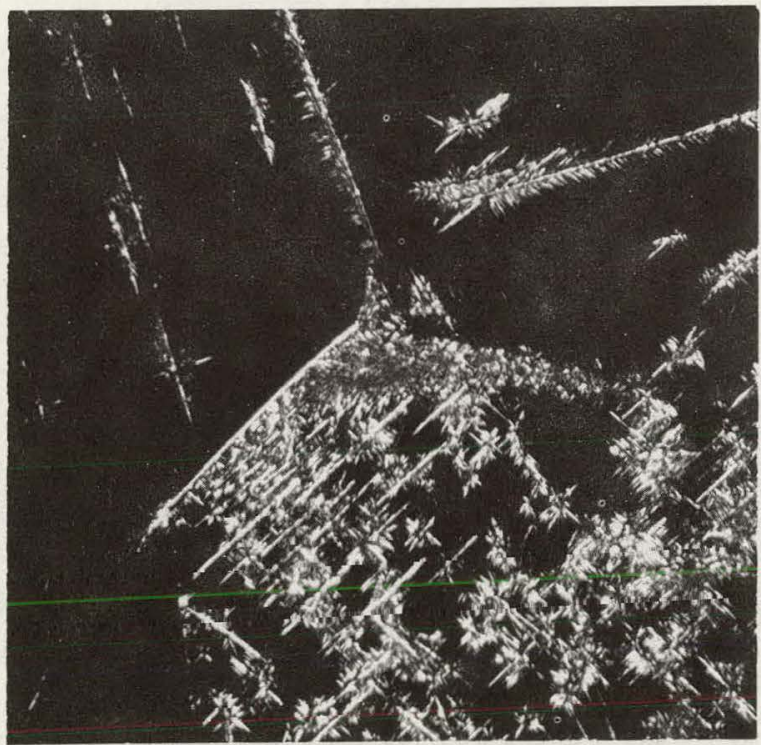

Neg. No. 20665

$\mathbf{x 5 0 0}$

Figure 9

Ti-22.5Cb-10A1-1Sn. As forged. Polarized light.

Etchant: $\mathrm{HHO}_{3}$, HF, $\mathrm{H}_{2} \mathrm{O}_{2}$, glycerine

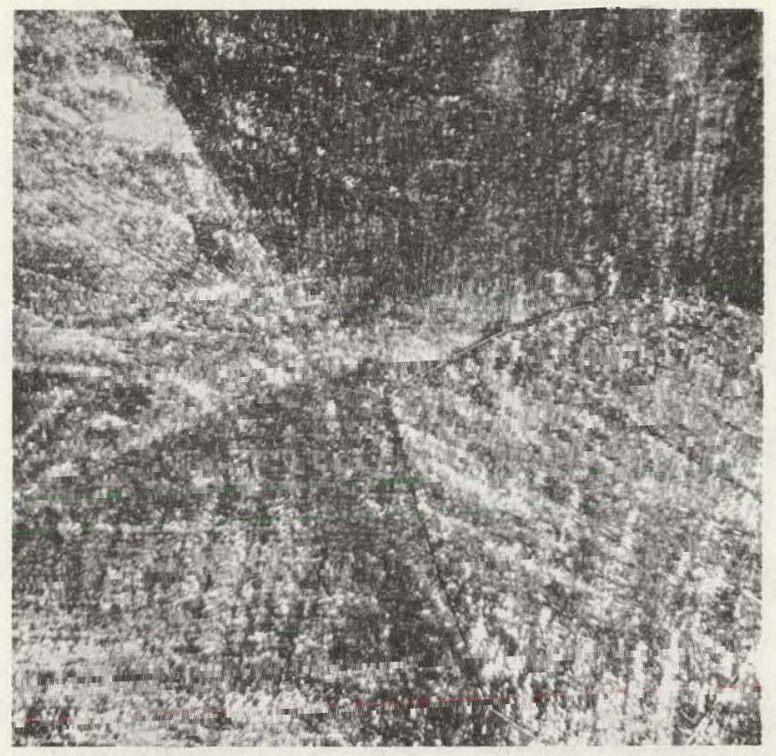

Neg. No. 20660

$\mathbf{X 5 0 0}$

Figure 8

Ti-22.5Cb-7.5Al-1Sn. As forged. Polarized light.

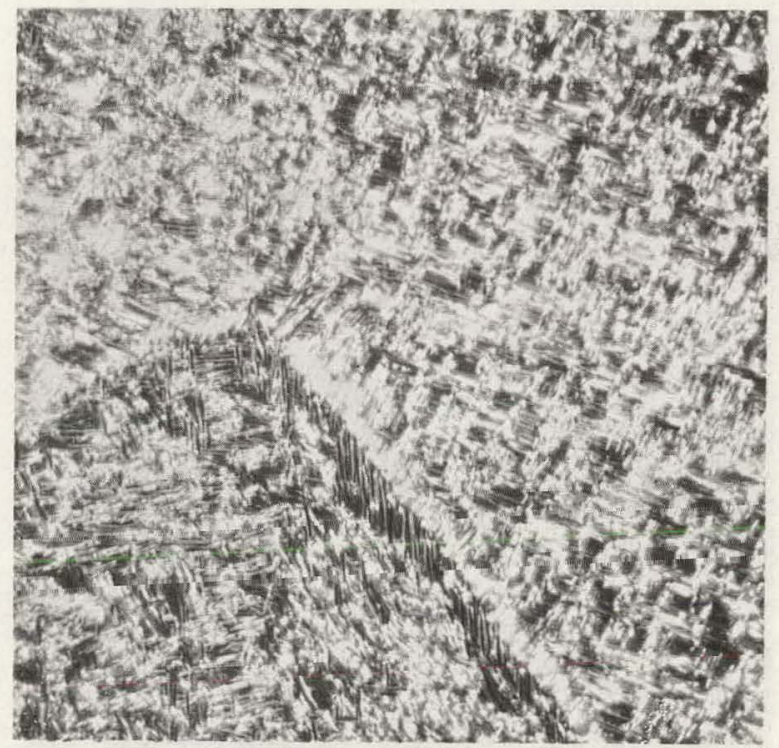

Neg. No. 20685

$\mathbf{X 5 0 0}$

Figure 10

I1-22.5Cb-15Al-0.5Zr. As forged. Polarized light. 


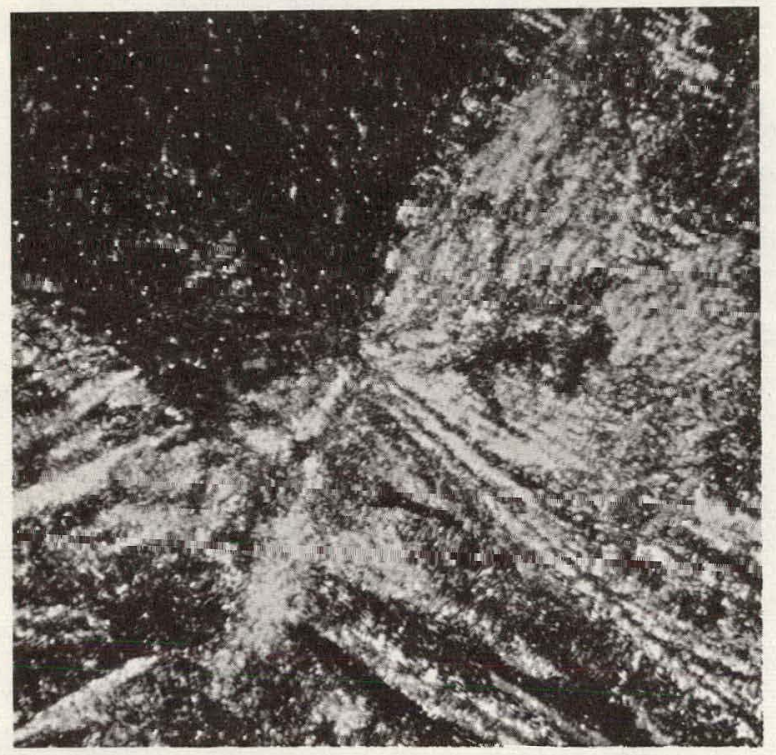

Nleg. No. 20669

$\mathbf{1 5 0 0}$

Figure 11

Ti-22.5Cb-7.5Al-5Sin. As forged. Polarized light.

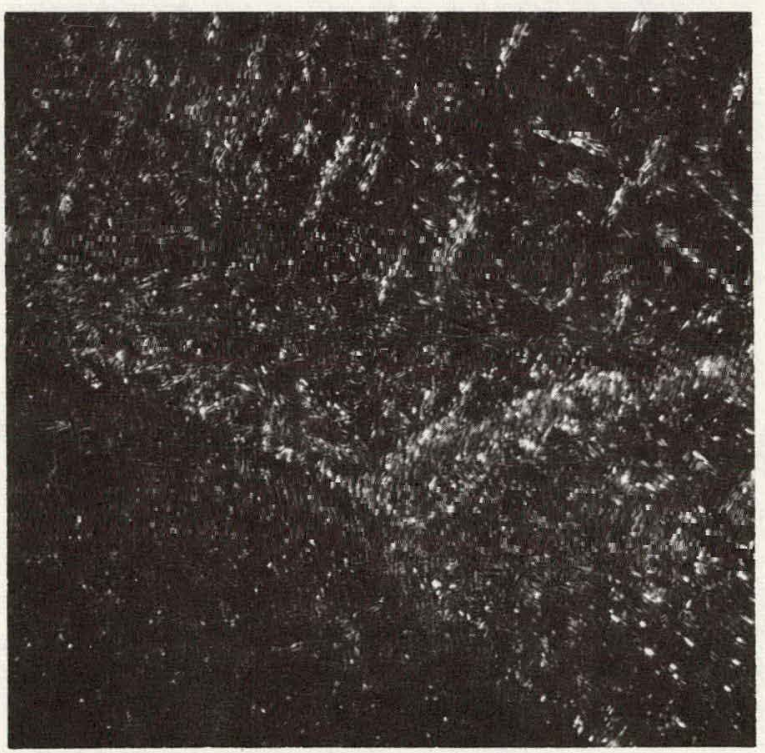

Neg. No. 20664

$\times 500$

Figure 13

Ti-22.5Cb-12.5A]-5Sn. As forged. Polarized light.

Itchant: $\mathrm{HNO}_{3}$, HF, $\mathrm{H}_{2} \mathrm{O}_{2}$, glycerine

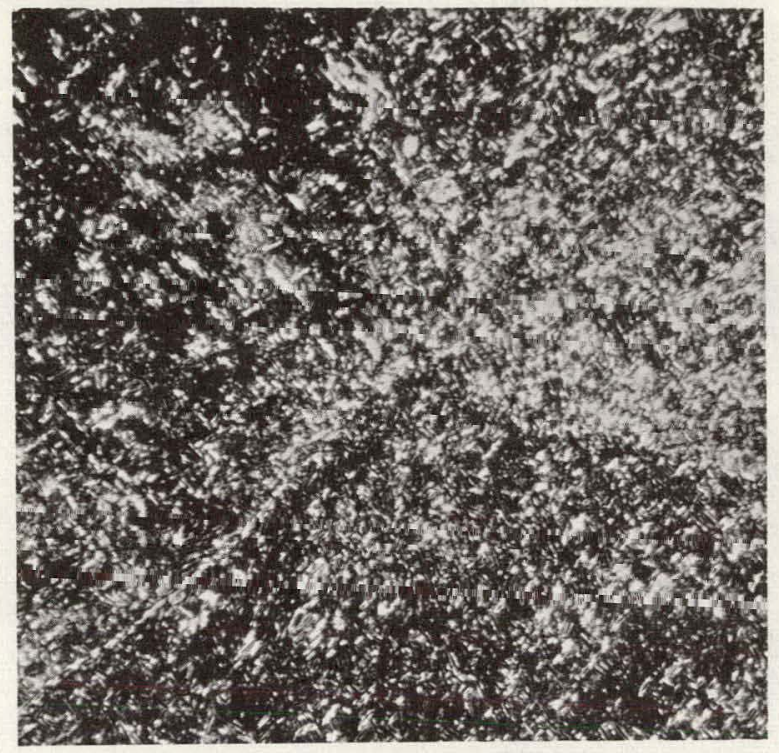

Neg. No. 20678

$\times 500$

Figure 12

T1-22.5Cb-10Al-5Sn. As forged. Polarized light.

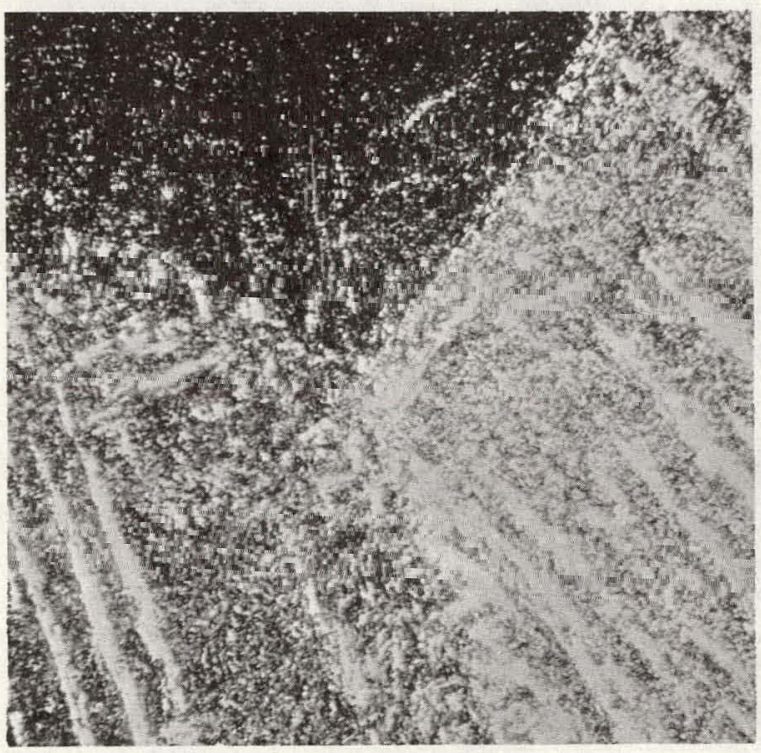

Neg. No. 20668

$\times 500$

Figure 14

Ti-22.5Cb-10Al-1Hf. As forged. Polarized light. 


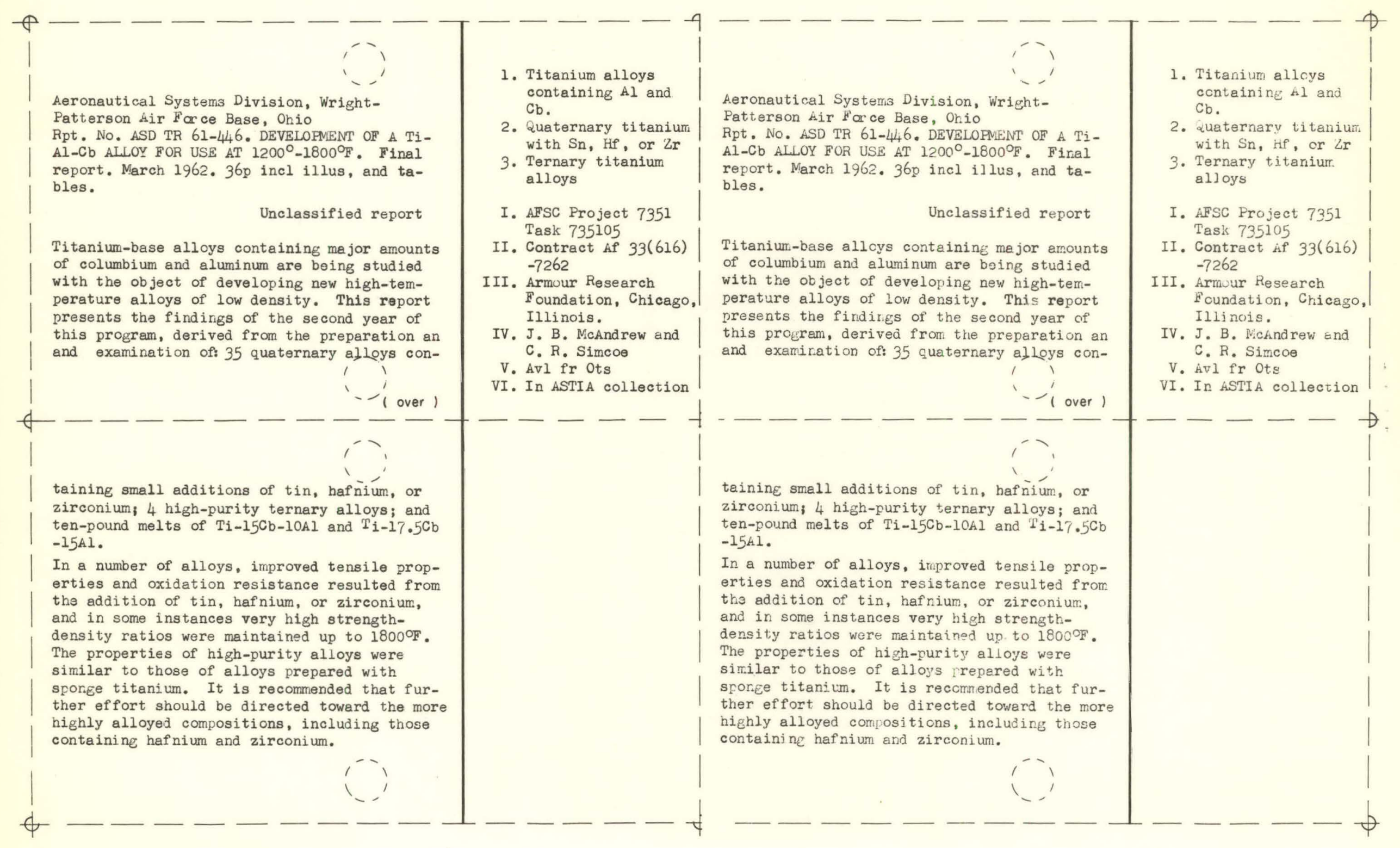

